\title{
IS LABOR PRODUCTIVITY LINKED to REAL WAGES? AN EMPIRICAL STUDY of the TURKISH MANUFACTURING SECTOR
}

\author{
Özge KORKMAZ1
}

\begin{abstract}
Purpose: Effective employment policies play a crucial role in national economic strategies. Therefore, exploring the relationship between labor force productivity and real wages is of particular importance for policymakers. Amid the lively debate on the relationship and causal factors related to labor productivity and real wages, this study carefully examines the data related to these factors between 1988:Q1 to 2006:Q4 and 2007:Q1 to 2017:Q4.

Methodology: In this study, the ARDL Bounds and Toda-Yamamoto causality tests are utilized to analyze the data from both periods.

Findings: Different results were found for each period. Although the results varied in the long-term and the short-term, this study's key results suggest there is significant evidence of a long-term relationship among the variables for the first period. There is no evidence of a long-term relationship between the unemployment rate, labor productivity per hour and real wages in the second period.

Originality: Unlike other studies in the literature, it was examined the relationship between labor productivity and real wages in the Turkish manufacturing industry separately before and after the 2008 financial crisis and also, two different variables were considered for productivity. Partial (labor) productivity was analyzed for the first period and labor productivity per hour for the second period. Keywords: Labor Productivity, Manufacturing Sector, Real Wages, Unemployment Rate, Turkey.

\section{iŞ GÜCÜ VERIMLILiĞi REEL ÜCRETLER ILE ILIŞKILI MI? IMALAT SEKTÖRÜ ÜZERINE AMPIRIK BIR ÇALIŞMA}

\section{ÖZET}

Amaç: Etkili istihdam politikaları, ulusal ekonomik stratejilerde önemli bir rol oynar. Bu nedenle, iş gücü verimliliği ile reel ücretler arasındaki ilişkinin araştırılması politika yapıcılar için özellikle önemlidir. İş gücü verimliliği ve reel ücretlerle ilgili tartışmalar özelinde, bu çalışmanın amacı, 1988:Q1-2006:Q4 ve 2007:Q1-2017:Q4 dönemleri için iş gücü verimliliği ve reel ücretler arasındaki ilişkiyi incelemektir.

Yöntem: Çalışmada ARDL Sınır Testi ve Toda Yamamoto Nedensellik Testinden yararlanılmıştır.

Bulgular: Analiz sonuçlarına göre, iki dönem için farklı sonuçlar bulunmaktadır. Sonuçlar, ilk dönem için değişkenler arasında uzun vadeli bir ilişki olduğuna dair önemli kanıtlar olduğunu göstermektedir. İkinci dönemde ise işsizlik oranı, saat başına iş gücü verimliliği ve reel ücretler arasında uzun vadeli bir ilişki olduğuna dair bir sonuç bulunamamıştır.

Özgünlük: Literatürdeki çalışmalardan farklı olarak, imalat sanayi sektöründe iş gücü verimliliği ve reel ücretler arasındaki ilişki, 2008 Krizi öncesi ve sonrası olarak ayrı ayrı incelenmiştir ve ayrıca verimliliği ölçmek için iki farklı değişken ele alınmıştır. İlk dönem için kısmi (iş gücü) verimliliği, ikinci dönem için saat başına iş gücü verimliliğiyle çalışılmıştır.

Anahtar Kelimeler: İ̧̧ Gücü Verimliliği, İmalat Sektörü, Reel Ücretler, İşsizlik Oranı, Türkiye.

\footnotetext{
1 Associate Professor, Malatya Turgut Özal University, Faculty of Social and Humanities Sciences, Department of Management Information Systems, ozge.korkmaz@ozal.edu.tr, ORCID: 0000-0001-9275-1271

DOI: 10.51551 verimlilik.692326

KORKMAZ, Ö. (2021), Is Labor Productivity Linked to Real Wages? An Empirical Study of the Turkish Manufacturing Sector, Verimlilik Dergisi, Sayı: 2, 25-48.

Araştırma Makalesi / Research Article | Geliş Tarihi / Received Date: 21.02.2020 | Kabul Tarihi / Accepted Date: 22.01.2021
} 


\section{INTRODUCTION}

Economic growth, higher productivity and creating appropriate levels of employment have historically been a crucial part of the objectives for macroeconomic policymakers. For developing countries, in particular, economic growth has consistently been the top priority among these objectives. At the same time, increases in the rates of economic growth are often considered a positive indicator of economic stability. For example, the increase in the growth rate after the 2001 crisis in Turkey is often considered a major economic success (Korkmaz and Yılgör, 2010). Although the Turkish economy has demonstrated a sustained rate of growth since 2001 , unemployment rates have remained high. This situation has led to discussions and debates about whether the economic growth is genuine and stable or whether it is failing to reach wider sectors of the economy, including the labor market. This type of growth can be called employment-free growth and this phenomenon is often attributed to an increase in labor productivity from technological developments or a type of growth that limits investments due to high costs (Saraçoğlu and Suiçmez, 2008). It is worth mentioning that increases in global competition, the globalization of trade, and increases in labor productivity are often considered to be the main reasons for global unemployment (Kaynak, 2006). Therefore, it is clear that changes in labor productivity (often defined as production per employee or per hours worked) have undeniable effects on the economy and particularly on the labor market. Specifically, changes in labor productivity are frequently reflected in the share of labor from production and real wages.

It is generally argued that an increase in average real wages is a result of increases in productivity, since increases in labor productivity cause the marginal labor income to rise. This implies that an increase in real income can thus be distributed to workers (Güneş, 2007). In order to reach a desired and expected level of increase in labor productivity is primarily due to an increase in overall productivity. However, this is based on crucial investments in technology such as new production technologies or new production methods, which as a result increases employment. However, if there is a decline in overall employment, while the production level remains constant or is even increasing, this type of situation can be quite problematic. Turkey finds itself in this situation (Sapancalı, 2008: 16). In Turkey, economic growth is pressing forward, but desired levels of employment continue to remain elusive. Therefore, a study of the dynamics of labor productivity particularly within Turkey can contribute valuable insight to this area of research and can also include policy implications.

In order to analyze labor productivity, it is necessary to take the concept of wage into consideration. A wage is sum of money paid in return for the value added to production by one's labor. In other words, there is an undeniable connection between productivity and how it can affect wages. However, this connection is not always explicitly evident. Furthermore, in some models, the causal direction can also be reversed from wage growth to labor productivity. Models based on efficiency wage theory assume that wage increases will increase the level of dedication and loyalty of their employees and hence their productivity. In another model, where the qualifications of employees cannot be measured directly, there is a high salary approach to ensure the most qualified staff are being utilized. Moreover, according to another point of view, a high-wage policy decreases labor turnover in businesses and minimizes the costs that may arise for this reason (Krueger and Summers, 1988). Yet, this relationship may differ from country to country, from labor market to labor market, particularly in the long term. For example, between 1960 and 2000, a decrease was observed in economic growth rates in line with productivity and wages. Similarly, in the case of a depletion of human capital, a positive or negative interaction can both be observed between productivity and wages. For example, wage increases provided through collective bargaining, as well as wage regulations made by the state, can increase productivity and lead to a positive relationship between the two variables. However, in the case where there are wage increases without increasing productivity, a negative relationship occurs between productivity and wages (Akyıldız and Karabıçak, 2002). This study explores the relationship between productivity and wages by examining these dynamics within the Turkish manufacturing industry. An autoregressive distributed lag (ARDL) Bounds testing approach and causality tests are applied to the data between 1988:Q1 and 2006:Q4 and between 2007:Q1 and 2017:Q4. 
This study differs from others in the literature in the following ways:

- In the study, two different periods are analyzed in Turkey. Thus, the study allows an opportunity for comparing and contrasting data over multiple time periods.

- In this study, the correlation between labor productivity and wages is examined in detail by considering the effect of structural breaks for both periods.

- There are no current data set variables for wages in Turkey. In the literature, wages have been studied in Turkey by using only variable earnings per hour. In this study, it is thought that the effect of inflation on wages should be adequately considered. Therefore, real wages are computed as earnings per hour/CPI.

- In this study, two different variables are considered for productivity. Partial (labor) productivity is used for the first period and labor productivity per hour is used for the second.

- In the study, the unemployment rate is analyzed but it is not provided for the quarterly data for the first period. Consequently, it is included in the analysis only for the second period.

- Although comparisons between the sectors can be useful, sufficient data for an econometric analysis from other sectors is not available in Turkey. For this reason, comparing the relationship between productivity and wages over multiple periods is applied for just the manufacturing sector.

The paper is structured accordingly: In Section 2, we discuss the current evidence and findings regarding the productivity-wage relationship in the literature. Section 3 is the empirical approach to the study and the dataset. The specific empirical findings are presented in Section 4 and the conclusion and policy implications are outlined in Section 5.

\section{CONCEPTUAL FRAMEWORK}

Since the relationship between real wages, productivity and unemployment rates has significant links in the labor market, it attracts considerable attention in the economics literature. Wage theories are typically grouped into traditional wage theories and modern wage theories. Examples of traditional wage theories are the natural wage theory, the wage fund theory, the exploitation theory of wages, the marginal productivity theory and the collective bargaining theory. Types of modern wage theories are the purchasing power theory, the theory of the natural rate of unemployment, the insider-outsider theory, the efficiency wage theory and the implicit labor contract theory. Some of these theories assert causal relationships between the variables, while others argue the opposite. Some modern wage theories such as the efficiency wage theory and the collective bargaining theory, suggest causal links between each of these variables (Wakeford, 2004). Classical economists, that were formative in the creation of various economic schools of thought, argued that the labor factor is homogeneous and changes in real wages do not affect the productivity of labor. In other words, the changes that occur in the labor demand curve explain the changes in the real wages. Furthermore, according to the classical model, in a labor market where perfect competition conditions exist, real wages are determined according to the equilibrium of supply and demand. In this type of situation, it is claimed that unemployment in the labor market is voluntary. In other words, according to classical economists individuals in this situation prefer to remain unemployed instead of working at real wage rates which are determined by the labor market (Çetin and Bakırtaş, 2014). Contrary to classical economists, Philips (1958) suggested that there is a causal relationship between wages and the unemployment rate in his study of the UK economy. Phelps (1967) and Friedman (1968) took the analysis one step further and stated that this relationship only occurs in the short term. Thus, in sum, it is clear that there are multiple approaches to understanding the relationship between these variables. For this reason, an intentional engagement with both traditional and modern wage theories is necessary for the study.

\subsection{Traditional Wage Theories}

According to the natural wage model, the proper level of wages depends on the cost of labor. The cost of labor is the minimum living wage required for a worker to survive. From this perspective, a wage is a sum of money that is paid to a worker at a sufficient level to provide for a necessary level of consumption 
for the worker to survive. The main factor determining the wage level is the physical needs of the worker (Smith, 1997: 65). The theory suggests that wage, as a cost of labor, is determined according to supply and demand conditions within the market, just like other goods. According to this theory, labor has a natural price and a market price, like all other goods. While the natural price refers to the level of income that is necessary for a worker to cover his or her basic expenses to survive, the market price is formed according to the supply and demand within the labor market. According to this theory, wage levels are explained by population growth and the labor force is characterized as expensive when it is scarce and cheap when it is abundant (Öztürk, 2005).

The wage fund theory is based on the possibility of allocating an amount of cash that can be used to pay wages. The wage fund concept has been adopted as an explanation of the wage level. In this theory, wages are determined according to the relationship between the population size and the capital that is used to pay wages. This theory, developed by John Stuart Mill, depends on the demand for labor and, consequently, on the size of a particular fund determined by the pre-existing capital in production. The level of wages is obtained by dividing this fund by the number of workers employed. The capital allocated to pay the wages at a certain time arises from the sale of goods produced in the previous period. Labor demand is determined by the wages which relate to the previous period's production and the wage of the worker depends on the size of the capital available at a given time. According to this theory, only an increase in the capital stock and the wage fund will increase wage rates.

Marx wants to show the inequity of non-labor earnings such as rent, profit, interest and other income in the capitalist system under a model called the exploitation theory of wages. According to Marx (2000: 150-158), the source of capitalist accumulation is profit. Profit expectation is the main factor affecting the investments of capitalists. For this purpose, the capitalist pays the workers, turns their labor into marketable products by employing them, and makes a profit by selling these goods at a higher price than the costs to produce them. According to this theory, labor is the only factor that creates value, and the value of a good is determined by the amount of labor expended to produce that good. Therefore, all the value created as a result of production must be paid to the worker as a wage. A system where the worker is paid at a subsistence level and the remaining part (excess value) goes to the capital owners as profit, would be seen by Marx as exploitation. In a capitalist system, profit and interest, according to Marx, are stolen from the workers, and hence they are called unfair revenues. From this perspective, the working conditions of capitalism cause the exploitation of the labor force. In other words, although it is labor that produces all the wealth, the laborers only receive the minimum amount of wages to survive and the excess-value is seized by the employer (Öztürk, 2005; Brunhoff, 1992: 15-16).

According to the marginal productivity theory, labor is the only variable that determines profit maximization in the short-term under the conditions of perfect competition. Profit maximization is the minimization of labor costs. In this context, an equilibrium between production and employment will occur if the marginal product of labor (MPL) for an additional employee is equal to the marginal cost and real wages (W/P). Therefore, in order to increase the marginal productivity of labor, it is necessary to increase real wages. This type of classical approach establishes a direct relationship between wage and productivity increases (Güneş, 2007; Yıldırım, 2015). For example, each production factor has a share in production according to the neoclassical marginal productivity theory (Saraçoğlu and Suiçmez, 2008). This means that workers with a high level of productivity are paid higher and workers with less productivity are paid less. At a macroeconomic level, an increase in real wages is expected to increase the cost of labor. Therefore, additional labor is expected to increase marginal productivity until labor productivity reaches a level of equilibrium (Goh, 2009: 4).

The collective bargaining theory understands that wages are not only formed by the functioning of the supply and demand mechanism in the labor market, but wages are formed and affected by many factors. Wages are determined as a result of negotiations or agreements between workers and employers, and the bargaining power of the parties plays a primary role in determining the wage levels. The maximum amount of wages indicates the highest rate of wage the employer can pay and the minimum amount 
that can be agreed upon indicates the lowest rate. There are many wage rates between these two levels, and the bargaining power of the parties ensures that the wage rate falls between these two limits (Yalçıntaş, 1969: 53). In wage negotiations, when the upper limit of a specific wage is exceeded, the employer's share is not sufficient to continue production, while a figure below the lower limit is not sufficient to sustain a worker's livelihood. Within these limits, workers and employers agree on a wage level through mutual negotiations for many reasons (Dobb, 2007: 203-204). According to this theory, during times of low unemployment, there is less potential competition in the labor market and as a result, labor unions are in a better position to negotiate and achieve wage increases. So this model suggests that nominal wages can increase faster as the unemployment rate decreases. Conversely, real wages are expected to fall if there is a rise in the unemployment rates since unions will lose their bargaining power (Doğruyol and Aydınlar, 2015).

\subsection{Modern Wage Theories}

The purchasing power theory rejects the neoclassical wage models, which claim that the economy as a whole has a tendency to equilibrium with full employment. It argues that unemployment is a problem of effective demand rather than a wage problem and that changes in wages are not necessarily sufficient to change the demand for labor (Kregel, 1983: 50-68). The profitability of an industry depends on the availability of demand to meet the sale of goods produced at an affordable price. The vast majority of goods produced by industries are consumed by workers and their families. If the workers' wages and thus the purchasing power are high, the demand for goods may be sufficient. Therefore, the production of these goods will continue at a high level. When wages and purchasing power fall, production decreases and unemployment increases. If production cannot be increased in the face of increasing purchasing power, inflationary pressure will arise (Lordoğlu et al., 1999:146). In this context, the main purpose for supporters of this theory is to ensure that the level of wages is high enough to buy all of the products which are produced by the laborers and therefore prevent curtailing the level of production and intensifying the unemployment problem.

According to the natural rate of unemployment theory, as long as wages are flexible and government intervention is restrained, the labor market tends to spontaneously reach full employment equilibrium (Lazear, 1984:1-14). The natural rate of unemployment theory rejects the view that a fall in the unemployment rate can be achieved with high inflation. So it affirm that there is a trade-off between inflation and unemployment. The theory draws attention to market-clearing price levels and argues that the economy will spontaneously and rapidly return to the natural rate of unemployment determined by the various institutions within the economy. Unemployment, according to the natural rate of unemployment theory, is caused by supply-side distortions such as a misalignment in skills and the labor market or individual deterrent effects caused by excessive government intervention. Unemployment is seen as a result of the choices individuals make between work and leisure. According to this approach, governments can achieve positive economic results such as low unemployment and high productivity with microeconomic reforms (Mitchell and Muysken, 2008: 9-11).

It is also possible to understand the relationship between productivity and wages with an approach developed by new Keynesian economists called the insider-outsider theory. The theory explains the distribution of unemployment in different sectors and the relative wage structure in the context of a heterogeneous labor market (Eren et al., 2000). The model is based on the influential work of Lindbeck and Snower (1985-1986). This approach accepts the existence of two types of workers identified as 'insiders' or 'outsiders', meaning those inside a firm who are already employed and those outside who are unemployed, respectively. Unemployment, according to this model, will continue if the labor activity of outsiders and insiders and their bargaining power is not balanced and if firms are not then reaching out to outsiders (Bildirici, 2012: 10). In this context, changes in wages do not directly affect the level of unemployment since insiders play a significant role in setting wage levels that can create disincentives for outside hiring. High wages, in this case, are often endured for the sake the labor productivity. Therefore, macroeconomic theory assumes that according to the insider-outsider model, there is no direct relationship between wages and unemployment rates. 
Another theory that explains the wage-productivity relationship is the efficiency wage theory. This theory assumes that wages influence productivity. Specifically, by employing higher-wage workers beyond the market-clearing wage, firms can typically reduce employee turnover, limit inefficiency and therefore enhance their overall productivity. For instance, in this theory, raising a worker's pay is thought to encourage a higher level of work engagement and strengthen an employee's commitment to the firm in the long-term. In its analysis of the productivity-wage relationship, "human capital stock" and "physiological loading" are the basic criteria. The relationship between these criteria may be negative, positive, or neutral at a national level. This depends on the relative relationship between them. For example, if productivity in an economy increases and the return on human capital stock drops the relationship between wages and productivity is negative. Moreover, if we consider changes made in the private business sector, as a result of increased productivity, the level of human capital stock and physiological loading required by the respective jobs may either decrease or increase. Therefore, the relationship between wages and productivity can vary. When this situation is analyzed over the short term, these two variables are generally observed to have a positive relationship. But in the long term, this relationship has a structure that typically can shift from either neutral to negative (Akyıldız and Karabıçak, 2002).

The implicit labor contract theory strives to explain the role of legitimate agreements and their economic effects between firms and employees that are negotiated agreements, but not formal (Parasız, 1994: 195-196). This theory attempts to explain wage rigidity through long-term implicit contracts between risk-averse workers and risk-exposed firms. According to this theory, implicit agreements are the most important factor in shaping long-term relationships between workers and firms. Firms can refer to unwritten agreements to keep workers, and the implicit agreement provides guarantees to workers when working conditions begin to change. This model was developed based on the observation that firms do not simply change their employment structure and their wages quickly even when the demand for the goods produced by the firm changes. There is an implied agreement that the workers are more or less guaranteed a fixed wage. Thus, while the firm carries the risk in this agreement, the workers are able to shield themselves from a significant measure of risk. However, according to this theory, firms may not face more risk on the whole than the workers due to the overall wealth differences between the two (Brown, 1980: 1-69; Parasız and Bildirici, 2002; Öztürk, 2005: 45-46).

\subsection{Empirical Literature}

The empirical literature on productivity and wages focuses on two broad themes. For example, many studies observe a significant relationship between productivity and wages such as Katowich and Maia (2018) for Brazil, Dostie (2006) for Canada, Fedderke and Mariotti (2002) for South Africa, Özmucur (2003) for Turkey, Marquetti (2004) for the United States, Strauss and Whoar (2004) for US manufacturing industries, Güneş (2007) for the Turkish manufacturing sector, Sharpe et al. (2008) for Canada, Goh (2009) for Malaysia, Klein (2012) for South Africa, Bhattacharya et al. (2009) for the Indian manufacturing sector and Meghan (2002) whose study covers multiple industrialized countries. On the other hand, Tadjoeddin (2016) found a post-crisis disconnect between wages and productivity in Indonesia. Later, Tadjoeddin and Chowdhury (2019) also found a similar disconnect in Indonesia's manufacturing sector between productivity and wages.

A survey of the empirical literature on the subject suggests that there are a substantial number of studies that have analyzed the relationship between productivity and real wages. However, most of these studies have concentrated on data related to developed countries. For instance, both Strauss and Wohar (2004) and Narayan and Smyth (2009) investigated this relationship using a panel cointegration analysis while focusing on data from the United States and G7 countries. The former study explored the causal links in 459 manufacturing industries in the United States; however, the latter study focused on the long-run elasticities of productivity regarding real wages and inflation for the G7 countries. Overall, the results from the studies that focus on developed countries generally show that there is a positive and strong relationship between productivity and real wages (Yıldırım, 2015). 
Similarly, studies related to the wage-employment relationship generally focus on the relationship via productivity. Harrison (2009) states that wage inequality expands the gap between real wages and productivity. Autor et. al. (2007) found that employment protection has a negative impact on the productivity of firms in the United States from 1970 to 1999. The adoption of various dismissal protection policies limited production options and led employers to retain unproductive workers. Likewise, Petrin and Sivadasan (2006) state that increasing the gap between a worker's marginal revenue product and their wages diminish productivity. Symeonidis (2008) investigated the effect of competition on wages and productivity in some manufacturing industries in the UK via a panel data analysis between 1954 and 1973. There was evidence that collusion negatively affected the growth of labor productivity, but it did not affect wages before or after the introduction of a cartel law.

Hsieh and Klenow (2009) investigated how the minimum wage affects a firm's productivity in the manufacturing industries of China and India from 1992 to 2005. According to the results of the analysis, an increase in the minimum wage caused a decrease in a firm's productivity. Fachin and Gavosto (2010) examined labor productivity trends in Italy from 1981 to 2004 and found a long-term relationship among the variables. Kaytanci's (2010) study on efficiency wage theory in Turkey from 1963 to 1998 concluded that wages were causally related to productivity. The study also found that the claims of efficiency wage theory were supported in some of the sectors under consideration.

Lopez and Silva (2011) examined the relationship between the wage-productivity gap and unemployment in OECD countries through a panel smooth transition regression model and a vector autoregression model from 1985 to 2007. They found what is called an exhibited nonlinear structure that shifted from positive to negative in situations where there is more rigid employment legislation. Elgin and Kuzubaş (2012) investigated the gap between real wages and productivity in manufacturing industries in Turkey particularly with respect to inflation, capital deepening, the size of the informal sector, and taxes from 1950 to 2009. The gap was seen to be a consequence of the bargaining power of the workers. Moreover, a positive relationship was also seen between the wage-productivity gap and unemployment. Das et. al. (2017) analyzed the influence of wages on labor productivity using a panel causality test for India's manufacturing industry between 1998 and 2013. Using variables such as employment, productivity, and wages the conclusions showed there was not a significant causal relationship from productivity to employment and wages. In other words, the wage rate was not affected by productivity. Álvarez and Fuentes (2018) examined the relationship between the minimum wage and productivity in Chile's manufacturing industry from 1992 to 2005 using a dynamic panel data analysis. They analyzed the variables of wages, sales, output, and employment and showed that the relationship was negative due to labor adjustment costs. Dimian et al. (2019) employed a panel ARDL model to examine the salaryemployment nexus for Romania's 14 sectors. They submitted a negative association between these two variables, while there was a long-run association between these two variables in the short-run. Sectors varied this result. Employing Johansen and Juselius cointegration and Granger causality approaches for the Turkish industrial sector, Ağazade and Albayrak (2019) showed that labor productivity was negatively influenced by increased employment long-run while a raise in employment penetrated real wage raises positively. In short-run, their results indicated the presence of the bidirectional causality among labor productivity and employment. Applying Johansen and Johansen/Juselius cointegration and VECM analyses, Bakır and Eryılmaz (2020) posed the long-run among these variables and the causality operating from real wage to employment in the short-run for the Turkish manufacturing sector. Table 1 summarize the empirical literature. 
Table 1. Summary of Empirical Literature

\begin{tabular}{|c|c|c|c|c|c|}
\hline Author(s) & Country & Period & Variables & Method & Findings \\
\hline $\begin{array}{l}\text { Özmucur } \\
(2003)\end{array}$ & Turkey & $1950-1998$ & $\begin{array}{l}\text { Wage, prices and production } \\
\text { indices in nine two-digit } \\
\text { manufacturing sub-sectors, } \\
\text { real wage rate, real labor } \\
\text { productivity, labor force, GNP } \\
\text { per capita }\end{array}$ & $\begin{array}{l}\text { Three stage least } \\
\text { squares estimates }\end{array}$ & $\begin{array}{l}\text { Labor productivity is higher in } \\
\text { private sector while average } \\
\text { wage rate is higher in public } \\
\text { sector. }\end{array}$ \\
\hline $\begin{array}{l}\text { Marquetti } \\
(2004)\end{array}$ & $\begin{array}{l}\text { United } \\
\text { States } \\
\text { (US) }\end{array}$ & $1869-1999$ & $\begin{array}{l}\text { Real wages, labor } \\
\text { productivity }\end{array}$ & $\begin{array}{l}\text { Cointegration and } \\
\text { Granger non-causality } \\
\text { tests }\end{array}$ & $\begin{array}{l}\text { There is a relatonship } \\
\text { between real wages and labor } \\
\text { productivity in the long run. }\end{array}$ \\
\hline $\begin{array}{l}\text { Dostie } \\
(2006)\end{array}$ & Canada & $1999-2003$ & $\begin{array}{l}\text { Years of age, wage, labor } \\
\text { productivity, total hours } \\
\text { worked }\end{array}$ & $\begin{array}{lr}\text { Least } & \text { Square, } \\
\text { Restricted } & \text { Maximum } \\
\text { Likelihood } & \end{array}$ & $\begin{array}{l}\text { Concave age-wage and age- } \\
\text { productivity profiles are found. } \\
\text { Productivity of workers aged } \\
55 \text { and more with at least } \\
\text { an undergraduate degree is } \\
\text { lower than their wages. }\end{array}$ \\
\hline $\begin{array}{l}\text { Güneş } \\
\text { (2007) }\end{array}$ & Turkey & $1988-2006$ & $\begin{array}{l}\text { Labor productivity, wage } \\
\text { worked per hour in } \\
\text { maufacturing sector }\end{array}$ & $\begin{array}{l}\text { Cointegration, vector } \\
\text { autore regression } \\
\text { model, vector error } \\
\text { correction model }\end{array}$ & $\begin{array}{l}\text { There is long-term equilibrium } \\
\text { relationshi between } \\
\text { productivity and real wage }\end{array}$ \\
\hline $\begin{array}{l}\text { Hsieh ve } \\
\text { Klenow } \\
(2009)\end{array}$ & $\begin{array}{l}\text { China } \\
\text { and India }\end{array}$ & $1992-2005$ & $\begin{array}{l}\text { Labor productivity in } \\
\text { maufacturing sectors, } \\
\text { minimum wage }\end{array}$ & Quartile regression & $\begin{array}{l}\text { According to the results of } \\
\text { the analysis, an increase in } \\
\text { the minimum wage caused } \\
\text { a decrease in a firm's } \\
\text { productivity }\end{array}$ \\
\hline $\begin{array}{l}\text { Bhattacharya } \\
\text { et al. (2009) }\end{array}$ & India & $1973-2001$ & $\begin{array}{l}\text { Sectoral labor productivity, } \\
\text { real wage, employment }\end{array}$ & $\begin{array}{l}\text { Panel cointegration } \\
\text { analysis }\end{array}$ & $\begin{array}{l}\text { There are long-term } \\
\text { cointegration relationship } \\
\text { between productivity and } \\
\text { real wages and between } \\
\text { productivity and employment } \\
\text { Also, employment and real } \\
\text { wages have a positive effect } \\
\text { on labor productivity }\end{array}$ \\
\hline $\begin{array}{l}\text { Kaytancı } \\
(2010)\end{array}$ & Turkey & $1963-1998$ & Granger causality & $\begin{array}{l}\text { Average product } \\
\text { of labor per hour, } \\
\text { fixed wage per hour, } \\
\text { average product of } \\
\text { labor per worker, fixed } \\
\text { wage per worker }\end{array}$ & $\begin{array}{l}\text { Wages were causally related } \\
\text { to productivity. The study } \\
\text { also found that the claims of } \\
\text { efficiency wage theory were } \\
\text { supported in some of the } \\
\text { sectors under consideration. }\end{array}$ \\
\hline $\begin{array}{l}\text { Lopez and } \\
\text { Silva (2011) }\end{array}$ & OECD & $1985-2007$ & $\begin{array}{l}\text { Labor productivity gap, } \\
\text { unemployment, real wage }\end{array}$ & $\begin{array}{l}\text { Panel smooth } \\
\text { transition regression } \\
\text { model and a vector } \\
\text { autoregression model }\end{array}$ & $\begin{array}{l}\text { What is called an exhibited } \\
\text { nonlinear structure that shifted } \\
\text { from positive to negative in } \\
\text { situations where there is more } \\
\text { rigid employment legislation. }\end{array}$ \\
\hline $\begin{array}{l}\text { Elgin and } \\
\text { Kuzubaş } \\
(2012)\end{array}$ & Turkey & $1950-2009$ & $\begin{array}{l}\text { Unionization, unemployment } \\
\text { rate, inflation, tax rate, capital } \\
\text { deeping, MPL-to W ratio }\end{array}$ & 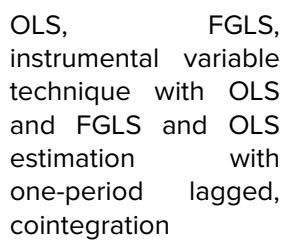 & $\begin{array}{l}\text { There is a positive relationship } \\
\text { wage-productivity gap } \\
\text { and unemployment rate in } \\
\text { manufacturing sector. }\end{array}$ \\
\hline $\begin{array}{l}\text { Tadjoeddin } \\
\text { (2016) }\end{array}$ & Indonesia & $2001-2012$ & $\begin{array}{l}\text { Earnings, labor productivity, } \\
\text { employment }\end{array}$ & $\begin{array}{l}\text { Generalised method } \\
\text { of moment }\end{array}$ & $\begin{array}{l}\text { The realtinship between real } \\
\text { wages and employment is } \\
\text { negative. }\end{array}$ \\
\hline
\end{tabular}


Table 1. (Continued)

\begin{tabular}{|c|c|c|c|c|c|}
\hline Author(s) & Country & Period & Variables & Method & Findings \\
\hline $\begin{array}{l}\text { Das et al. } \\
\text { (2017) }\end{array}$ & India & $1998-2013$ & $\begin{array}{l}\text { Employment, productivity } \\
\text { and wages }\end{array}$ & Panel causality & $\begin{array}{l}\text { There was not a significant } \\
\text { causal relationship from } \\
\text { productivity to employment } \\
\text { and wages. In other words, the } \\
\text { wage rate was not affected by } \\
\text { productivity. }\end{array}$ \\
\hline $\begin{array}{l}\text { Katowich } \\
\text { and Maia } \\
(2018)\end{array}$ & Brazil & $1996-2014$ & $\begin{array}{l}\text { Sectoral labor productivity, } \\
\text { labor formalization, national } \\
\text { monthly minimum wage, total } \\
\text { hours worked per sector, } \\
\text { years of age, proportion } \\
\text { famale, years of education }\end{array}$ & $\begin{array}{l}\text { Panel fixed regression } \\
\text { analysis }\end{array}$ & $\begin{array}{l}\text { Wage levels for all economic } \\
\text { sectors affect positively } \\
\text { productivity. Also, Ibor } \\
\text { formalization and minimum } \\
\text { wage have equal impacts on } \\
\text { productivity. }\end{array}$ \\
\hline $\begin{array}{l}\text { Álvarez and } \\
\text { Fuentes } \\
\text { (2018) }\end{array}$ & Chile & $\begin{array}{l}1992- \\
20015\end{array}$ & $\begin{array}{l}\text { Wages, sales, output, and } \\
\text { employment }\end{array}$ & Dynamic panel data & $\begin{array}{l}\text { The relationship between } \\
\text { wage and productivity } \\
\text { was negative due to labor } \\
\text { adjustment costs }\end{array}$ \\
\hline $\begin{array}{l}\text { Dimian et al. } \\
\text { (2019) }\end{array}$ & Romania & $1995-2016$ & $\begin{array}{l}\text { Total employment, and the } \\
\text { average net real monthly } \\
\text { salary earnings }\end{array}$ & Panel ARDL model & $\begin{array}{l}\text { There was a long-run linkage } \\
\text { between these two variables, } \\
\text { there was a negative linkage } \\
\text { in short-run. }\end{array}$ \\
\hline $\begin{array}{l}\text { Ağazade } \\
\text { and Albayrak } \\
\text { (2019) }\end{array}$ & Turkey & $\begin{array}{l}\text { 2005Q1- } \\
\text { 2016Q3 }\end{array}$ & $\begin{array}{l}\text { Labor productivity and total } \\
\text { industry employment index }\end{array}$ & $\begin{array}{l}\text { Johansen and } \\
\text { Juselius cointegration } \\
\text { and Granger causality }\end{array}$ & $\begin{array}{l}\text { Labor productivity was } \\
\text { negatively affected by } \\
\text { increase in employment in } \\
\text { long-run while increase in } \\
\text { employment penetrated real } \\
\text { wage raises positively. }\end{array}$ \\
\hline $\begin{array}{l}\text { Bakır and } \\
\text { Eryılmaz } \\
(2020)\end{array}$ & Turkey & $\begin{array}{l}\text { 1988Q2- } \\
\text { 2019Q4 }\end{array}$ & Real wages and employment & $\begin{array}{l}\text { Johansen and } \\
\text { Johansen/Juselius } \\
\text { cointegration and } \\
\text { VECM tests }\end{array}$ & $\begin{array}{l}\text { The causality run from real } \\
\text { wage to employment in the } \\
\text { short-run. }\end{array}$ \\
\hline
\end{tabular}

Source: The table is prepared by author.

\section{METHODOLOGY}

\subsection{Data and Variables}

This study examines the relationship between productivity and real wages. Productivity, in the most general sense, is a concept used to express how well an enterprise or an organization uses its resources to produce goods and services. In order to find the optimum level of maximizing resources, a proportional relationship should be established between the resources used and the products provided. It is possible to differentiate efficiency types under three headings, namely total productivity, multifactor productivity and labor productivity. Accordingly, productivity is calculated by the ratio of the total production factors to the total inputs. In order to find the optimum level of resources used, a proportional relationship should be established between the resources used and the products provided. Unfortunately, however, total productivity is difficult to calculate because the input components are very difficult to express using the same units of measure. For this reason, some have insisted that labor productivity calculations need to be considered individually instead of attempting to include all production factors in a general productivity calculation (Paksoy, 1999: 43 ). The productivity $\left(\mathrm{PR}_{1}\right)$ variable used in this study is the labor productivity index which includes data from the manufacturing industry in both the public and private sectors. The index is calculated by quarters and is expressed as production per hour worked. Similarly, the variable related to wages $\left(\mathrm{W}_{1}\right)$ is the quarterly real wage index calculated according to the hourly wage criteria for the manufacturing industry. The study period is from 1988:Q1 to 2006:Q4. All the variables are transformed into logarithmic form so that the coefficients can be interpreted as elasticities. The following notation is used for the two variables, $w_{1}=\log$ (real wage index), $=\log$ (partial [labor] productivity index). 
There are some limitations to the time dimension in this study. For example, there is no current data set for the wage and productivity variables. Therefore, different productivity and wage indicators are used for the variables in this study. Also, the period that is examined for these three variables is limited to $2007: Q 1$ to $2017: Q 4$. In other words, there is no current data for the variables. The unemployment rate is also used in the study. The variables that were used over the same period are the index of production per employee for the total industry $\left(P R_{2}\right) /$ index of hours worked $(\mathrm{HW})$, unemployment rate $(\mathrm{u})$ and the hourly earnings that exclude seasonal and calendar effects $\left(W_{2}\right) /$ consumer price index (CPI). The following notation is used for the three variables: $p_{2}=\log$ (labor productivity per hour index), $w_{2}=\log$ $\left(W_{2} / C P l\right)$ and $u=$ (unemployment rate). The real wage is calculated in Turkish liras (TL).

The data sets were obtained from the Central Bank of the Republic of Turkey's electronic data distribution system, the FRED database, and the Turkish Statistical Institute. Table 2 summarizes the statistics of the variables used in this study. ${ }^{2}$

Table 2. Statistics Summary

\begin{tabular}{|l|c|c|c|c|c|}
\hline & $\mathbf{w}_{\mathbf{1}}$ & $\mathbf{p}_{\mathbf{1}}$ & $\mathbf{w}_{\mathbf{2}}$ & $\mathbf{p}_{\mathbf{2}}$ & $\mathbf{u}$ \\
\hline Mean & 4,593918 & 4,575677 & $-0,4868$ & 4,6112 & 10,1590 \\
\hline Median & 4,577004 & 4,598237 & $-0,5229$ & 4,6114 & 10,1500 \\
\hline Maximum & 4,970754 & 5,128148 & $-0,2521$ & 4,7845 & 14,5000 \\
\hline Minimum & 4,041932 & 3,930558 & $-0,6451$ & 4,4013 & 7,5000 \\
\hline Std. Dev. & 0,197496 & 0,330284 & 0,1272 & 0,0700 & 1,5708 \\
\hline Skewness & $-0,268515$ & $-0,272057$ & 0,5945 & $-0,4750$ & 0,5858 \\
\hline Kurtosis & 3,848673 & 2,246392 & 2,0001 & 4,5942 & 3,0085 \\
\hline Jarque-Bera & 3,194049 & 2,735958 & 4,4205 & 4,3147 & 2,5174 \\
\hline p-value & 0,202498 & 0,254621 & 0,1096 & 0,1085 & 0,2840 \\
\hline Sum & 349,1378 & 347,7515 & $-21,4225$ & 202,8945 & 447,000 \\
\hline Sum Sq. Dev. & 2,925361 & 8,181542 & 0,6961 & 0,2107 & 106,1064 \\
\hline Observations & 76 & 76 & 44 & 44 & 44 \\
\hline
\end{tabular}

The descriptive analysis shows that the variables have a normal distribution at a $10 \%$ significance level according to Jarque-Bera normality test. $w_{1}, p_{1}$ and $p_{2}$ are left-skewed while $w_{2}$ and $u$ are right-skewed. The value of standard deviation for $w_{1}$ is higher value than $w_{2}$, which indicates $w_{1}$ has more volatility. Also, $p_{1}$ has higher standart deviation than $p_{2}$.

\subsection{Models}

In this study, we draw on the work of Koatovich and Maia (2018), Taştan and Akar (2013) and Güneş (2007) and the analysis focuses specifically on the long-term relationship between wages and productivity. Following the empirical literature, the standard log-linear functional specification of the long-term relationship real wage $\left(w_{1}\right)$ and partial productivity $\left(p_{1}\right)$ in the Turkish manufacturing industry may be expressed as:

$$
w_{1 t}=\beta_{0}+\beta_{1} p_{1_{t}}+\varepsilon_{t}
$$

$\beta_{0}$ and $\beta_{1}$ indicate parameters and $\varepsilon_{t}$ shows the error term in the Equation 2 . The second model includes three variables. The long-run relationship between real wage $\left(w_{2}\right)$, labor productivity $\left(p_{2}\right)$ per hour and the unemployment rate $(u)$ in the Turkish manufacturing industry may be expressed as:

$$
w_{2 t}=\alpha_{0}+\alpha_{1} p_{2 t}+\alpha_{2} u_{t}+v_{t}
$$

$a_{0}, a_{1}$ and $a_{2}$ indicates parameters and $v_{t}$ shows the error term in the Equation 3.

\footnotetext{
2 Many times the series exhibits a regular seasonal pattern over the year. Therefore, all variables are seasonally adjusted by the TRAMO-SEATS method (except real wages) in this study.
} 


\subsection{ARDL Bounds Testing Approach}

The existence of long-term relationships between the two variables will be investigated by the ARDL Bounds testing approach.

$$
Y_{t}=\gamma_{0}+\gamma_{1} X_{t}+v_{t}
$$

First, the ARDL method allows the variables to be $I(1)$ or $I(0)$ in order to investigate the cointegration relationship. The advantages of this method are that it does not require a unit root pretest (Pesaran and Pesaran, 1999) and it allows for the variables to have different optimal lags, which is impossible with conventional cointegration procedures. Equation 5 can be presented as the following in the ARDL form:

$$
\Delta Y_{t}=c+\alpha Y_{t-1}+\beta X_{t-1}+\sum_{i=1}^{k} \theta \Delta Y_{t-i}+\sum_{j=1}^{k} \delta \Delta X_{t-j}+\varepsilon_{t}
$$

In the equation $\varepsilon_{t}$ and $\Delta$ are the white noise term and the first difference operator, respectively. The appropriate lag selection is based on a Schwarz information or criterion (SIC). The bounds testing procedure is based on the joint F-statistic or Wald statistic that tests the null hypothesis of cointegration, $H_{0}: a=\beta=0$ against the alternative of $H_{1}: a \neq \beta \neq 0$. The $\mathrm{F}$ statistic is calculated for any significance level where it is possible to make a definite interpretation without considering the integration scores of the variables (Pesaran et al., 2001: 296). The null $\left(H_{0}\right)$ hypothesis is rejected in the case where the computed test statistic is higher than the upper critical bound value. However, the cointegration test becomes indeterminate when the F-statistic remains between the bounds. If the F-statistic is below the lower critical bound value, the null hypothesis cannot be rejected. Having found long-run relationships among the variables, the long-run relationship is then estimated using the following selected ARDL $(m, n)^{3}$ models in Equation 6. Whereas Equation 7 presents the vector error correction model (VECM):

$$
\begin{aligned}
& Y_{t}=\emptyset_{0}+\sum_{i=0}^{l} \alpha_{i} Y_{t-i}+\sum_{j=0}^{m} \beta_{i} X_{t-j}+\varepsilon_{1 t} \\
& \Delta Y_{t}=\emptyset_{1}+\sum_{i=1}^{k} \theta(i) \Delta X_{t-i}+\sum_{j=1}^{k} \delta \Delta(i) Y_{t-i}+\psi_{1} E C M_{t-1}+\varepsilon_{2 t}
\end{aligned}
$$

Equation 6, VECM 1; VECM 2 are shown in Equation 7. Thus, Equation 6 and Equation 7 VECM are estimated to determine the Granger causality between the variables:

$$
\Delta X_{t}=\emptyset_{2}+\sum_{i=1}^{k} \varphi(i) \Delta Y_{t-i}+\sum_{j=1}^{k} \phi \Delta(i) X_{t-i}+\psi_{2} E C T_{t-1}+\varepsilon_{3 t}
$$

$\varepsilon_{1 t}, \varepsilon_{2 t}$ and $\varepsilon_{3 t}$ show residual terms and they are independently and normally distributed with a zero mean and a constant variance. An optimal lag selection based on a criterion such as AIC and SIC where $\psi_{1}$ and $\psi_{2}$ are the coefficients of the error correction term (hereafter ECM and ECT) in Equation 7 and in Equation 8. The error correction term indicates how quickly the variables converge toward equilibrium. The coefficient of the error correction term should be statistically significant and negative.

\subsection{Toda-Yamamoto Causality Approach}

In the absence of a long-term relationship, the Toda-Yamamoto test is used to determine the presence of a causal relationship between variables. Long-term information loss is prevented by taking the difference during the causality test. In other words, since the unit root analysis is not necessary with a Toda-Yamamoto causality test, there is no need to stabilize the non-stationary series by taking the difference (Toda and Yamamoto, 1995). The Toda and Yamamoto (1995) equations for the study are as follows:

\footnotetext{
3 The lag lengths $m$ and $n$ are determined by Akaike information criteria (AIC) or Schwarz information criteria (SIC) following the suggestion of Pesaran and Pesaran (1997).
} 


$$
\begin{aligned}
& w_{t}=\delta_{0}+\sum_{i=1}^{k} \delta_{1 i} w_{2 t-i}+\sum_{j=k+1}^{d_{\max }} \delta_{2 i} w_{2 t-j}+\sum_{i=1}^{k} \beta_{1 i} p_{2 t-i} \sum_{i=1}^{d_{\max }} \beta_{2 i} p_{2 t-j}+ \\
& \sum_{i=1}^{k} \beta_{3 i} u_{t-i}+\sum_{j=k+1}^{d_{\max }} \beta_{4 i} u_{t-j}+v_{1 t} \\
& p_{2 t}=\theta_{0}+\sum_{i=1}^{k} \theta_{1 i} p_{2 t-i}+\sum_{j=k+1}^{d_{\max }} \theta_{2 i} p_{2 t-j}+\sum_{i=1}^{k} a_{1 i} w_{2 t-i} \sum_{j=k+1}^{d_{\max }} a_{2 i} w_{2 t-j}+ \\
& \sum_{i=1}^{k} a_{3 i} u_{t-i}+\sum_{j=k+1}^{d_{\max }} a_{4 i} u_{t-j}+v_{2 t} \\
& u_{t}=a_{0}+\sum_{i=1}^{k} a_{1 i} u_{t-i}+\sum_{j=k+1}^{d_{\max }} a_{2 i} u_{t-j}+\sum_{i=1}^{k} \gamma_{1 i} w_{2 t-i}+\sum_{j=k+1}^{d_{\max }} \gamma_{2 i} w_{2 t-j}+\sum_{i=1}^{k} \gamma_{3 i} p_{2 t-i}+ \\
& \sum_{j=k+1}^{d_{\max }} \gamma_{4 i} p_{2 t-j}+v_{3 t}
\end{aligned}
$$

In the MWALD Test, the direction of the causality relationship is determined by using VAR ( + dmax) (Toda and Yamamoto, 1995). For example, the null hypothesis for Equation 9 is that "Labor productivity per hour and the unemployment rate do not causally affect real wages" and the alternative hypothesis is that "labor productivity per hour and the unemployment rate causally affect the real wage". If the MWALD statistic is statistically significant, the alternative hypothesis is accepted and there is, in fact, a causal relationship from the independent variable to the dependent variable.

\section{EMPIRICAL FINDINGS}

\subsection{Results of the Unit Root Analysis}

In order to obtain reliable results, we examined the order of integration for the series. For this purpose, we applied the Augmented Dickey-Fuller (ADF), the Philips-Perron (PP) and the Kwiatkowski-PhilipsSchmidt-Shin (KPSS) unit root tests in this study. The results of the unit root test are presented in Table 3.

Table 3. ADF, PP and KPSS Unit Root Tests

\begin{tabular}{|c|c|c|c|c|c|}
\hline \multicolumn{5}{|c|}{ For Constant } & \multicolumn{2}{c|}{ PP } & KPSS \\
\hline Variables & t-Statistics & p-Value & t-Statistics & p-Value & t-Statistics \\
\hline$p_{1}$ & $-0,8455$ & 0,7999 & $-0,8534$ & 0,7976 & $1,1561^{c}$ \\
\hline$w_{1}$ & $-2,6982$ & $0,0791^{\text {a }}$ & $-2,7205$ & $0,0753^{\text {a }}$ & 0,1493 \\
\hline$p_{2}$ & $-1,2860$ & 0,6275 & $-0,9392$ & 0,7659 & 0,6863 \\
\hline$\Delta \pi_{2}$ & $-6,3594$ & $0,0000^{c}$ & $-9,0018$ & $0,0000^{c}$ & 0,5000 \\
\hline$w_{2}$ & 0,5145 & 0,9853 & 0,8474 & 0,8938 & $0,7955^{c}$ \\
\hline$\Delta w_{2}$ & $-8,1506$ & $0,0000^{c}$ & $-8,1506$ & $0,0000^{c}$ & 0,2711 \\
\hline$u$ & $-3,3180$ & $0,0203^{\mathrm{b}}$ & $-2,7762$ & $0,0701^{\mathrm{a}}$ & 0,1094 \\
\hline For Constant and Trend & & & & \\
\hline \multicolumn{2}{|c|}{ ADF } & & & PP & KPSS \\
\hline Variables & t-Statistics & $\mathbf{p - v a l u e}$ & t-Statistics & p-Value & t-Statistics \\
\hline$p_{1}$ & $-2,2073$ & 0,4784 & $-2,2049$ & 0,4798 & 0,1563 \\
\hline$w_{1}$ & $-3,4811$ & $0,0491^{\mathrm{b}}$ & $-2,7611$ & 0,2161 & 0,1463 \\
\hline$p_{2}$ & $-2,8763$ & 0,1799 & $-2,8280$ & 0,1956 & 0,0711 \\
\hline$\Delta p_{2}$ & $-6,3307$ & $0,0000^{c}$ & $-11,2854$ & $0,0000^{c}$ & $0,5000^{c}$ \\
\hline$w_{2}$ & $-1,8918$ & 0,6414 & $-1,7495$ & 0,7414 & $0,1981^{\mathrm{b}}$ \\
\hline$\Delta w_{2}$ & $-8,3607$ & $0,0000^{c}$ & $-8,4045$ & $0,0000^{c}$ & 0,0924 \\
\hline$u$ & $-3,3605$ & $0,0717^{\mathrm{a}}$ & $-2,7477$ & 0,2238 & 0,1123 \\
\hline
\end{tabular}

Note: The optimal number of lags for the ADF test was determined by the Schwarz Information Criteria (SIC). The maximum number of lags is taken as 8 and the parenthesis shows the optimal number of lags for the ADF test and the band interval for the PP test. The critical value at a \%1 significant level in the KPSS test is 0,7390 for a unit root test with the constant term. For a unit root test with the constant term and trend, the value was 0,2160. $a, b$ and c show the significance levels at 10\%, 5\% and $1 \%$ respectively. 
According to Table 3, the ADF and Philips-Perron unit roots test results and the KPSS test results are contradictory with respect to the variables. The conflicting results mean that a unit root test with a structural break is needed. A Perron (1997) breakpoint unit root test was used, and the results are reported in Table 4.

Table 4. Results of Perron (1997) Breakpoint Unit Root Test

\begin{tabular}{|c|c|c|c|c|c|c|}
\hline \multicolumn{3}{|c|}{ MODEL A } & \multicolumn{2}{|c|}{ MODEL B } & \multicolumn{2}{|c|}{ MODEL C } \\
\hline Variables & Test Statistic & Break Point & Test Statistic & Break Point & Test Statistic & Break Point \\
\hline$p_{1}$ & $-3,9763$ & 1991: Q1 & $-4,5520^{b}$ & 1991: Q4 & $-5,9840^{c}$ & 1993: Q4 \\
\hline$w_{1}$ & $-3,6407$ & 2000: Q4 & $-3,5801$ & 1991: Q2 & $-3,8141$ & 1994: Q1 \\
\hline$\Delta w_{1}$ & $-10,796^{c}$ & 1994: Q2 & $-10,288^{c}$ & 1994: Q3 & $-11,590$ & 1994: Q2 \\
\hline$p_{2}$ & $-3,3278$ & 2016: Q3 & $-3,2807$ & 2016: Q4 & $-3,2415$ & 2016: Q2 \\
\hline$\Delta p_{2}$ & $-6,6412^{c}$ & 2011: Q4 & $-6,4460^{c}$ & 2017: Q4 & $-5,8043^{c}$ & 2011: Q1 \\
\hline$w_{2}$ & $-3,8163$ & 2015: Q1 & $-3,7181$ & 2013: Q1 & $-3,8980$ & 2011: Q3 \\
\hline$\Delta w_{2}$ & $-9,2395^{c}$ & 2016: Q3 & $-9,1120^{c}$ & 2016: Q2 & $-9,1684^{c}$ & 2015: Q2 \\
\hline$u$ & $-4,0424$ & 2016: Q2 & $-4,0638$ & 2012: Q3 & $-3,9559$ & 2010: Q3 \\
\hline$\Delta u$ & $-4,7673^{a}$ & 2016: Q2 & $-4,3921^{a}$ & 2017: Q1 & $-5,0150^{a}$ & 2011: Q4 \\
\hline
\end{tabular}

Note: $a, b$ and c show statistical significance at $10 \%, 5 \%$ and $1 \%$ respectively. means the first difference of the variable. Critical values for Model A are -5,347, -4,8598, $-4,6073$ for $1 \%, 5 \%$ and $10 \%$ significance respectively. Critical values for Model B are $-4,2610,-4,5248,-5,0674$ for $1 \%, 5 \%$ and $10 \%$ significance respectively. Critical values for Model C are $-4,8939,-5,1757,5,7191$, for $1 \%, 5 \%$ and $10 \%$ significance respectively.

According to Table 4, all variables (except partial productivity) can be said to be stationary at the first difference.

\subsection{Results of Partial Productivity and Real Wage (1988-2006)}

First, the relationship between partial productivity and real wage is analyzed from 1988:Q1 to 2006:Q4 in Turkey. In this regard, the time series chart of these variables is examined in Figure 1.

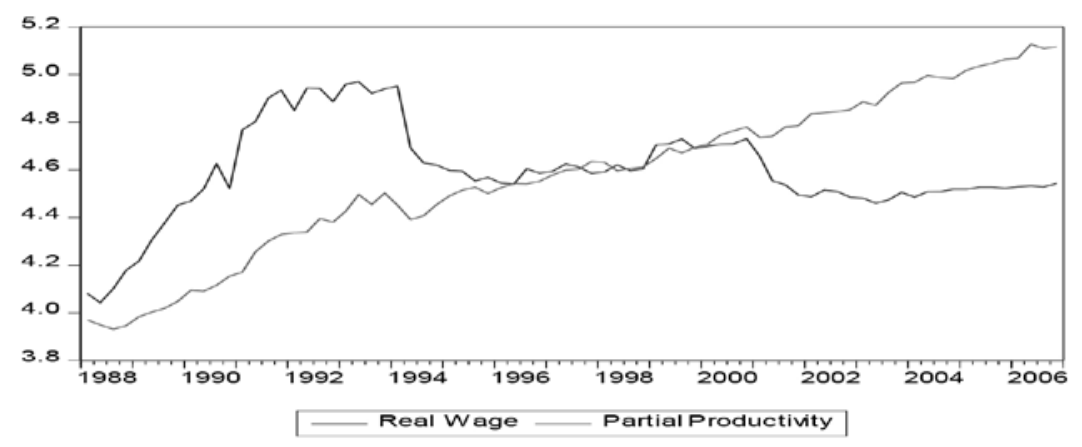

Figure 1. Real Wage and Partial Productivity, 1988-2006

The series is displayed in graphical form to detect trends and structural breaks. Partial productivity displays a relatively steady positive trend while the wage trend is interrupted by several shocks between 1988 and 2006. During this period, the Turkish manufacturing industry in particular shows layers of conflict and dissymmetry between wage and productivity. When we look at the trend of wages in Turkey after 1980, observed changes in microeconomic policies and the institutional structure of the labor market resulted in a period of instability. With the increasing importance of engaging in global competition in the 1980 s, real wages fell sharply. In other words, a tendency toward decreasing productivity was stronger in the post-1980 period (Kılıçaslan, 2005: 17). Toward the end of the 1980s, the liberalization of trade union activities and the effects of general growth on the economy led to a 
considerable rise of productivity and wages that compensated for the losses recorded in the previous period (Saraçoğlu and Suiçmez, 2008). A significant portion of the increase in the Turkish manufacturing sector's real wages occurred between 1989 and 1991. Although real wages continued to increase up until 1993, this increase was relatively low. With the outbreak of the economic crisis of 1994, the rate of real wages decreased sharply as the inflation rate increased around 100\% (Taymaz et al., 2014). After the 1994 crisis, bottlenecks in profitability, as well as increasing pressure from public budget deficits, caused a decline in both the private and public sectors, and this was equally observed in the manufacturing industry. Partial productivity reached its highest levels during the 2001-2006 period.

Following the unit root analysis, the relationship between the variables in the study is explored through the ARDL Bounds testing approach. The results of the cointegration test are given in Table 5 and the stability results are shown in Figure 2.

Table 5. Results of the Cointegration Test ${ }^{4}$

\begin{tabular}{|c|c|c|c|c|c|c|}
\hline \multicolumn{7}{|c|}{ Unrestricted Intercept and no Trend Case } \\
\hline \multicolumn{3}{|c|}{ Lags } & \multicolumn{2}{|c|}{ F-Statistic } & \multicolumn{2}{|c|}{ t-Statistic } \\
\hline \multicolumn{3}{|c|}{7} & \multicolumn{2}{|c|}{8,0817} & \multicolumn{2}{|c|}{$-3,7227$} \\
\hline \multicolumn{7}{|c|}{ Pesaran Critical Value } \\
\hline \multicolumn{3}{|c|}{$\% 10$} & \multicolumn{2}{|c|}{$\% 5$} & \multicolumn{2}{|c|}{$\% 1$} \\
\hline k & $I(0)$ & I(1) & $I(0)$ & I(1) & $I(0)$ & I(1) \\
\hline 1 & 4,04 & 4,78 & 4,94 & 5,73 & 6,84 & 7,84 \\
\hline
\end{tabular}

Note: Critical boundary values are taken from Table F Case l(iii) of Pesaran and Pesaran (2001: 300). $k$ is the independent variable number. In this study, structural shocks were determined by looking at the CUSUM and the CUSUMQ tests and then they were added as dummy variables in this model.

As seen in Table 4, there is a long-term relationship among these variables in the Turkish manufacturing industry. This is an expected result according to economic theory.
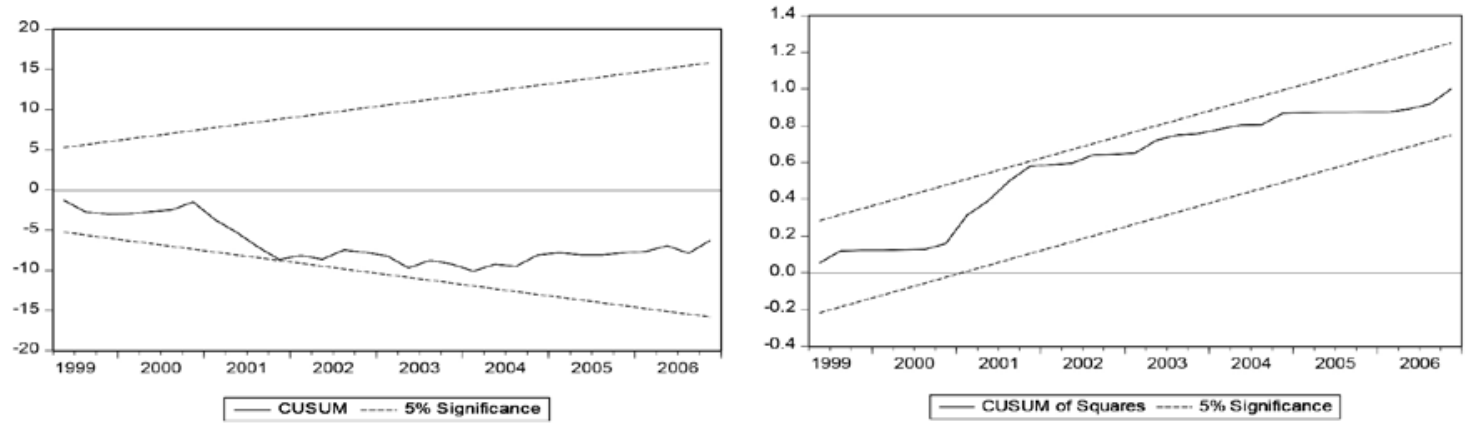

Figure 2. Plot of CUSUM and CUSUMQ Tests for the Cointegration Model

At this stage of the study, the optimal ARDL $(2,3)$ model was determined according to the Akaike information criterion (AIC) and this model is reported in Table 6.

\footnotetext{
${ }^{4}$ Structural breaks are included in the model and are used as a dummy variable.
} 
Table 6. ARDL $(2,3)$ Model

\begin{tabular}{|c|c|c|c|c|}
\hline \multicolumn{5}{|c|}{ Dependent Variable: $\mathbf{w}_{1 t}$} \\
\hline Variable & Coefficient & Standard Error & t-Statistic & p-Value \\
\hline Constant & 0,8214 & 0,1662 & 4,9402 & $0,0000^{c}$ \\
\hline$D_{1}$ & $-0,0285$ & 0,0151 & $-1,8765$ & $0,0651^{a}$ \\
\hline$w_{1 t-1}$ & 0,5442 & 0,1108 & 4,9103 & $0,0000^{\circ}$ \\
\hline$w_{1 t-2}$ & 0,3118 & 0,1027 & 3,0350 & $0,0035^{c}$ \\
\hline$p_{1 t}$ & 0,7179 & 0,2048 & 3,5048 & $0,0008^{c}$ \\
\hline$p_{t t-1}$ & 0,2343 & 0,1379 & $-1,6986$ & $0,0986^{a}$ \\
\hline$p_{1 t-2}$ & $-0,3465$ & 0,1326 & $-2,6118$ & $0,0112^{b}$ \\
\hline$p_{1 t-3}$ & $-0,5447$ & 0,2902 & $-1,8765$ & $0,0651^{a}$ \\
\hline \multicolumn{5}{|c|}{ Long Run Coefficients } \\
\hline Constant & 5,7095 & 0,6966 & 8,1960 & $0,0000^{\circ}$ \\
\hline$p_{1 t}$ & $-0,28704$ & 0,1562 & $-1,7310$ & $0,0882^{a}$ \\
\hline$D_{1}$ & $-0,0351$ & 0,0167 & $-2,1017$ & $0,0687^{b}$ \\
\hline
\end{tabular}

$R^{2}=0,9277 \quad F=119,2122\left(0.0000^{\circ}\right)$

$\overline{\mathrm{R}}^{2}=0,9199$ Jarque-Bera: $6,3005\left(0,042^{*}\right)$

Breusch-Godfrey LM. $2,0340(0,1393)$

Breusch-Pagan Godfrey 2,8424 $\left(0,0120^{* *}\right)$

Note: The symbols $a, b$ and c denote significance at \%10, \%5 and \%1 levels, respectively. ${ }^{*}$ shows that the error terms are normally distributed at a $1 \%$ significance level. ${ }^{* *}$ indicates the homoscedasticity is valid for $1 \%$ significance. p-values are given in parentheses.

When Table 6 is taken into consideration, it can be said that structural shocks $\left(D_{1}\right)$ and productivity index $\left(p_{1 t}\right)$ have a significant effect on long-term real wages $\left(w_{t}\right)$. In the long term, it is concluded that increases in partial productivity in the current period $\left(p_{1}\right)$, positively affect real wages but that the two previous increases in partial productivity $\left(p_{1 t-2}\right)$ have a negative impact on real wages.

When the long-term coefficients are examined, a $1 \%$ increase in partial productivity decreases wages by $28 \%$. Therefore, for the Turkish manufacturing industry in the long term, increases in partial productivity have not caused increases in real-wage. The statistics obtained from the autocorrelation, changing variance, normality, and the model-building-error tests are acceptable. At the same time, the CUSUM and CUSUMQ graphs also show that the regression coefficients are stable (see Figure 3 ).
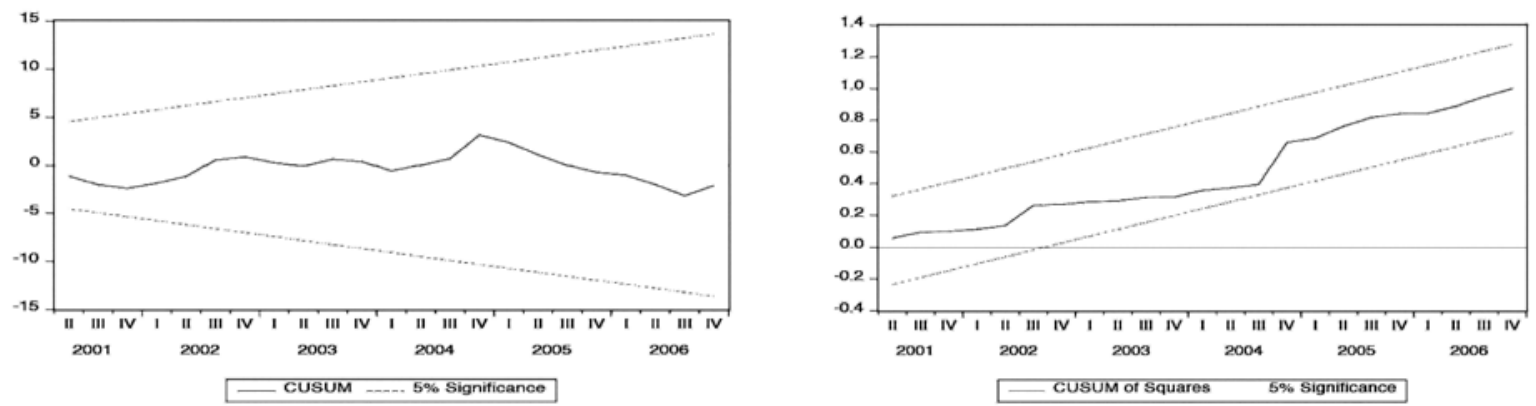

Figure 3. Plot of CUSUM and CUSUMQ tests for the ARDL $(2,3)$ Model

In the study, the results of the estimation of the vector error correction models are given in Table 7. 
Table 7. Vector Error Correction Model (VECM)

\begin{tabular}{|c|c|c|c|c|}
\hline \multicolumn{5}{|c|}{ Dependent Variable: $w_{1 t}$} \\
\hline Variable & Coefficient & Standard Error & t-Statistic & $\mathrm{p}$-Value \\
\hline Constant & 0,8214 & 0,1740 & 4,7207 & $0,0000^{\circ}$ \\
\hline$D_{1}$ & $-0,0281$ & 0,01370 & $-2,0752$ & $0,0490^{\mathrm{b}}$ \\
\hline$\Delta w_{1 t-1}$ & $-0,3118$ & 0,1071 & $-2,9115$ & $0,0014^{c}$ \\
\hline$\Delta p_{1 t}$ & 0,7117 & 0,2149 & 3,3401 & $0,0001^{c}$ \\
\hline$\Delta p_{1 t-1}$ & 0,8912 & 0,2192 & 2,4847 & $0,0155^{b}$ \\
\hline$\Delta p_{1 t-2}$ & 0,5447 & 0,2192 & 2,4847 & $0,0419^{b}$ \\
\hline $\mathrm{ECM}_{\mathrm{t}-1}$ & $-0,1438$ & 0,0297 & $-4,8325$ & $0.0000^{\circ}$ \\
\hline
\end{tabular}

$R^{2}=0,4390 \quad F=8,6101\left(0,0000^{c}\right)$

$\overline{\mathrm{R}}^{2}=0,3880$ Jarque-Bera: $6,3005\left(0,0428^{* *}\right)$

Breusch-Godfrey LM: $2,0340(0,1393) \quad$ Breusch-Pagan Godfrey :2,8424 $\left(0,012^{* *}\right)$

\begin{tabular}{|c|c|c|c|c|}
\hline \multicolumn{5}{|l|}{ Dependent Variable: $\boldsymbol{p}_{\boldsymbol{1}-\mathrm{t}}$} \\
\hline Variable & Coefficient & Standard Error & t-Statistic & p-Value \\
\hline Constant & 0,0065 & 0,0186 & 0,3525 & 0,7255 \\
\hline$D_{1}$ & $-0,003$ & 0,0101 & $-0,3455$ & 0,7308 \\
\hline$\Delta p_{1 t-1}$ & $-0,2070$ & 0,1184 & $-1,7481$ & $0,0852^{\mathrm{a}}$ \\
\hline$\Delta w_{1 t}$ & 0,1743 & 0,0513 & 3,3947 & $0,0012^{\mathrm{c}}$ \\
\hline$\Delta w_{1 t-1}$ & 0,1101 & 0,0516 & 2,1320 & $0,0368^{\mathrm{b}}$ \\
\hline$\Delta w_{1 t-2}$ & $-0,0941$ & 0,0507 & $-1,8537$ & $0,0638^{\mathrm{a}}$ \\
\hline$E C T_{\mathrm{t}-1}$ & $-0,0047$ & 0,0072 & $-0,6585$ & 0,5125 \\
\hline
\end{tabular}

$R^{2}=0,2292 \quad F=3,2717\left(0,0000^{c}\right)$

Breusch-Godfrey LM: 1,4155 $(0,2504)$
$\overline{\mathrm{R}}^{2}=0,1591$ Jarque-Bera: $3,0382(0,2189)$

Breusch-Pagan-Godfrey: 0,7282 (0,6486)

Note: The symbols $a, b$ and $c$ denote significance at $\% 10, \% 5$ and $\% 1$ levels respectively. $p$-value is given in parentheses.

The error correction term $\left(\mathrm{ECM}_{\mathrm{t}-\mathrm{o}}\right)$ in the first error correction model is negative and statistically significant as expected. The coefficient of the error correction term $\left(E C M_{t-1}\right)$ is $-0,1438$. This result shows that approximately $14 \%$ of the deviation from the balance disappeared in the first year and that the deviation will disappear after nearly seven periods (years). In the case of any shock to the wage index, the speed of reaching the equilibrium level is significant.

The error correction term $\left(E C T_{t-1}\right)$ in the second error correction model is negative but statistically insignificant. This result shows that changes in real wages have no effect on productivity in terms of long-term balance. Therefore, it cannot be inferred that these results support the predictions of the efficiency wage models.

According to the results of the VECM model, the increases in the current period $\left(p_{1 t}\right)$ and the previous period $\left(p_{t+1}, p_{t+2}\right)$ have a positive effect on wages in the short term. At the same time, it is concluded that the wage increases in the current $\left(w_{1 t}\right)$ and previous periods $\left(w_{1 t-1}\right)$ have a positive effect on productivity. This positive relationship between partial productivity and real wages in the short term is in line with the results of Özmucur (2003) and Marquetti (2004). Another remarkable finding in Table 6 is the negative effect on partial productivity of the previous three-period wage increases by around $9 \%$. This result indicates that increases in real wages and its effects on partial productivity have decreased as time passes.

Finally, when both VECM models are analyzed together, there is a one-way causality relationship from real wages to partial productivity because $\Sigma \theta_{i} \neq 0$. As is well known, efficiency wage theory argues that causality runs from real wages to partial productivity (Yıldırım, 2015). Therefore, this result indicates that 
this part of the efficiency wage theory is valid. Hence, the increase in real wages in the previous period seems to have a negative effect of around $15 \%$ on partial productivity.

\subsection{Results of Labor Productivity, Real Wage and Unemployment (2007- 2017)}

At this stage of the study, the relationship between the real wage, labor productivity and unemployment are analyzed for Turkey from 2007:Q1 to 2017:Q4. The results of the cointegration test are given in Table 8 and the relationship among the variables are examined in the time series chart in Figure 5 . As seen in Table 8, there is no long-term relationship among these variables.

Table 8. Result of the Cointegration Test

\begin{tabular}{|c|c|c|c|c|c|c|}
\hline \multicolumn{7}{|c|}{ Unrestricted Constant and Unrestricted Trend } \\
\hline \multicolumn{3}{|c|}{ Lags } & \multicolumn{2}{|c|}{ F-Statistic } & \multicolumn{2}{|c|}{ t-Statistic } \\
\hline \multicolumn{3}{|c|}{1} & \multicolumn{2}{|c|}{1,0667} & \multicolumn{2}{|c|}{$-1,0634$} \\
\hline \multicolumn{7}{|c|}{ Pesaran Critical Value } \\
\hline \multicolumn{3}{|c|}{$\% 10$} & \multicolumn{2}{|c|}{$\% 5$} & \multicolumn{2}{|c|}{$\% 1$} \\
\hline k & $\mathrm{I}(0)$ & $I(1)$ & $I(0)$ & $I(1)$ & $I(0)$ & $I(1)$ \\
\hline 2 & 4,19 & 5,06 & 4,87 & 5,85 & 6,34 & 7,52 \\
\hline
\end{tabular}

Note: Critical boundary values are taken from Table F Case I(v) of Pesaran and Pesaran (2001:300). $k$ is the independent variable number. In this study, structural shocks were determined by looking at the CUSUM and the CUSUMQ tests and then they were added as dummy variables in this model.
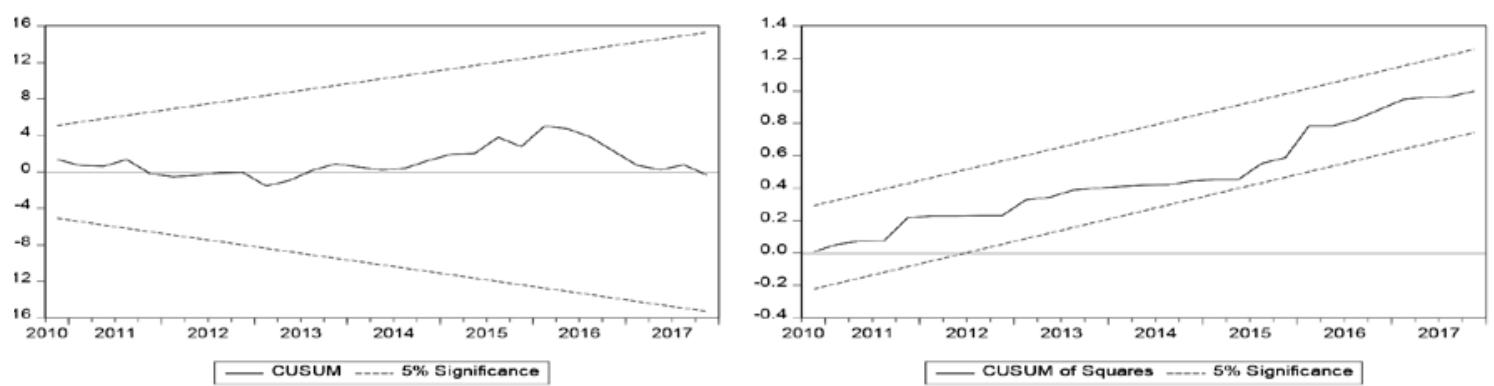

Figure 4. Plot of CUSUM and CUSUMQ Tests for the Cointegration Model

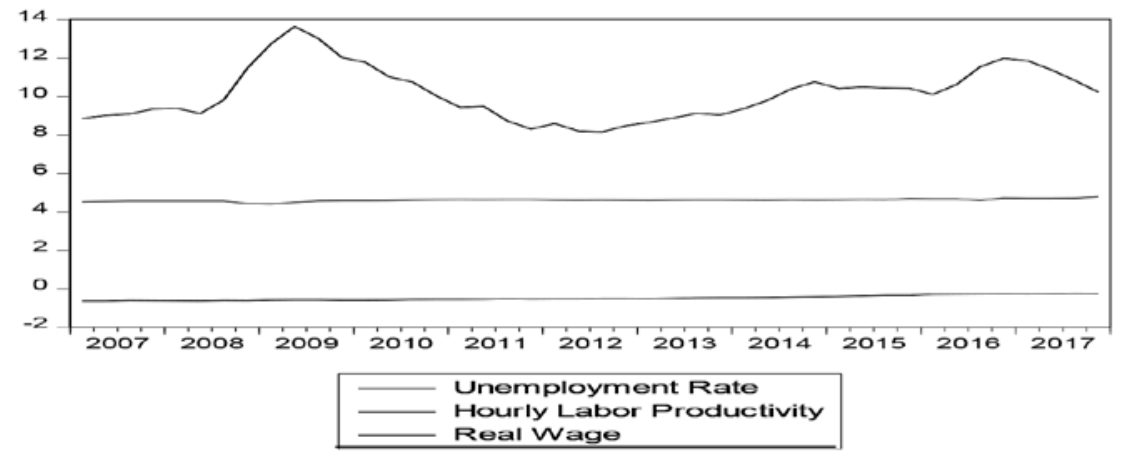

Figure 5. Real Wages, Labor Productivity and Unemployment, 2007-2017

Following the 2008 Crisis in Turkey's manufacturing industry, a significant gap occurred between productivity and wages as seen in Figure 5. In addition, real wages were continuously below labor productivity per hour during this period. When considering both Figure 5 and Table 7, the most important problem with the labor market in Turkey during this period is that wages are consistently lagging behind the inflation rate. This leads to a break in the causal relationship between wage increases and productivity. The second most important problem for Turkey is the disconnect between productivity, 
economic growth, and employment. The main factor for this disproportionate type of relationship is that economic growth is primarily consumption led. Other factors breaking the causal link between productivity and wage growth are that unemployment rates have remained stubbornly high.

In this study, the existence of a causal link among these variables in Turkey from 2007:Q1 to 2017:Q4 has been analyzed through the Toda-Yamamoto causality test and the causality results are summarized in Table 9.

\section{Table 9. Results of Toda-Yamamoto Causality Analysis ${ }^{5}$}

\begin{tabular}{|c|}
\hline Decision \\
\hline$p_{2}, u \neq>w_{2}$ \\
\hline$w_{2}, u=>p_{2}$ \\
\hline$w_{2}, p_{2}=>u$ \\
\hline
\end{tabular}

Note: => shows causality, $\neq>$ shows no causality.

The analysis shows that labor productivity per hour and the unemployment rate do not cause changes in real wages, but the combination of the other variables have causal effects. It is expected that both real wages and unemployment lead to productivity. In other words, an increase in the unemployment rate creates indirect pressure on employees to work more efficiently to maintain their jobs. Similarly, wage increases are also shown to lead to greater productivity.

The causality dynamics among unemployment, wages, and productivity is as expected. Namely, a twoway causal relationship is found even though there is no long-term relationship for the second period.

\section{CONCLUSION}

The globalization of trade and increases in labor productivity due to increasing global competition are generally seen as the main causes of global unemployment. Hence, changes in labor productivity are seen to play a crucial role in the labor market, especially in labor's share of production and real wages. Therefore, this study investigates how the manufacturing sector for different periods, is impacted and includes implications for future productivity studies. Similarly, this study provides the opportunity to make comparisons over multiple time periods with two different variables related to labor productivity.

According to the OECD Labor Force Statistics (2017), Turkey has the lowest labor force participation rate $(57,9 \%)$ in the OECD. Turkey also ranks quite low with reference to minimum wage compared to other OECD countries that enforce a minimum wage. In terms of productivity, however, Turkey has trends that indicate growth and development in the 2016-2017 period. The 2017 data in Turkey show a low employment rate, low wages and high productivity which suggest that discerning the relationship among these variables may be quite insightful. Furthermore, the sector in Turkey that has the highest productivity is the industrial sector. In other words, recently it has been observed that companies in the industrial sector could not repay their loans to banks operating in Turkey. As a result, employee wages have fallen and, at the same time, there has been an increase in the unemployment rate. For this reason, the manufacturing sector, which is the sector that uses most of the commercial credit, is the focus of this study.

In this study, based on the empirical findings, two important inferences are drawn regarding the relationship between productivity and wages. First, the findings show there is a long-term relationship between wages and productivity between 1988:Q1 and 2006:Q4. This result is in line with the findings of other studies in the literature such as Lopez and Silva (2011), Meghan (2002), Fedderke and Mariotti (2002), Özmucur (2003), Marquetti (2004), Strauss and Whoar (2004), Güneş (2007), Sharpe et al. (2008), Goh (2009), Marelli and Signorelli (2010), Fashin and Gavosto (2010), Klein (2012), Dostie (2006), Bhattacharya et al. (2009), Karaalp-Orhan (2017), Katowich and Maia (2018) and Dimian et al. (2019). Another result obtained from the study is that from wages to productivity there is a one-way causal

\footnotetext{
5 The details of the analysis are in Appendix I-II-III.
} 
effect. This result is also consistent with the findings of other studies in the literature (Güneş, 2007; KaytancI, 2010; Taymaz et al, 2014). Furthermore, it can be shown that structural shocks (D) and partial productivity $\left(\Pi_{1 t}\right)$ have a significant effect on the long-term real wage $\left(w_{t 1}\right)$.

For the first period, the changes in the productivity index have a negative effect on the wage index in the long term, whereas in the short term changes in the productivity index show a positive effect on the wage index. Thus, the effect of productivity on wages in the Turkish manufacturing sector varies from the short term to the long term during the same period.

Historically, during the 1988-1989 period in Turkey the economy entered into a period of low growth or what might even be called a recession. While the capacity utilization rates were low in the economy, zero growth was expected in 1989 but election investments were made that year and a 2\% growth actually occurred. The 1990-2000 period saw chronic high inflation, populist policies, wage increases, and it was even a period when real wages were higher than productivity. The total period from 1988 to 2006 covered in the study was a period of continuous turbulence and crises for the Turkish economy. It is commonly known that there were extensive cyclical movements during this period that included high uncertainty, high inflation and more intense financial activities than real activities. Therefore, the relationship between productivity and wages that are expected in this type of economy is consistent with the findings of this study. In other words, it was natural for short-term productivity increases to follow wage increases at that time.

One can infer that the reason for the negative relationship between productivity and wages, in the long run, is the existence of chronic high inflation and long-term contracts. As inflation increased between 1988 and 2006, real wages decreased and real activities decreased (financial activities also increased) and thus overall productivity in the economy decreased. While there was a positive relationship between productivity and wages in the short term, wages increased as employee contracts expired, and economic turbulence and low productivity continued simultaneously. In this case, a negative relationship between productivity and wages emerged in the long run. The crisis continued and when private sector layoffs began, there was high-to-low hidden unemployment during this period. The empirical findings obtained from the study reflect the economic instability in Turkey and its expected effects during this first period.

Whereas for the second period, there was no long-term relationship among productivity, real wages, and the unemployment rate. During this period, the inflation rate and the unemployment rate were both high and the causal relationship between the variables was absent. This is largely due to the fact that firms often did not accurately reflect wage increases and their overall financial position. During this second period, for example, many businesses struggled financially with large commercial debts and the number of firms that went bankrupt in the industrial sector substantially increased. Similarly, despite productivity gains, wages sunk against inflation due to persistent financial problems among private businesses in general. Therefore, in the long run, the causal relationship among these variables did not continue throughout the second period. Similarly, this situation is also consistent with the results of the causality analysis that show that productivity and the unemployment rate do not cause changes in wages. Therefore, it can be argued that the financial problems of businesses in the manufacturing industry should be directly addressed and that during periods of high inflation wage increases must be prioritized.

Despite the high unemployment rate, worker's fears of losing their jobs continued to sustain steady productivity levels. But the contradictory unemployment situation is caused by productivity and real wages. If productivity causes a rise in real wages, the output does not stimulate investments. Therefore, sufficient employment opportunities cannot be created and eventually the unemployment rate continues to remain high. The real wages are caused by unemployment, however, the lack of causation in the other direction shows the link is not fully connected.

Based on the results obtained from this study, it is recommended in future studies to consider additional variables related to labor productivity in order to make productivity comparisons across industrial sectors and develop more refined employment and productivity policies. 


\section{REFERENCES}

ADAŞ, C. G. (2002), Etkin Ücret Hipotezi, İşsizlik ve Ücret Rijitliği, İstanbul Üniversitesi İktisat Fakültesi Mecmuası, $52(1), 103-156$.

AĞAZADE, S. and ALBAYRAK, N. C. (2019), Türkiye'de Sanayi Sektöründe Emek Verimliliğ̣i, İstihdam ve Ücretler, Verimlilik Dergisi, 4, 7-24.

AKYILDIZ, H. and KARABIÇAK, M. (2002), Verimlilik Ücret İlişkisinin Analizi, Süleyman Demirel Üniversitesi İktisadi ve İdari Bilimler Fakültesi, 7 (2), 52-76.

ÁLVAREZ, R. and FUENTES, R. (2018), Minimum Wage and Productivity: Evidence from Chilean Manufacturing Plants, Economic Development and Cultural Change, 67 (1), 1-53.

ARIÇAY, Y. and PAKSOY, H. M. (1999), Bir Yaşam Tarzı ve Düşünce Bilimi Olan Prodüktiviteye Etkisi Bakımından Değerlemesi, Standart Dergisi, 455 (38), 42-48.

AUTOR, D. H., KERR, W. and KLUGER, A. D. (2007), Does Employment Protection Reduce Productivity? Evidence from US States, The Economic Journal, 117 (521), 189-217.

BAKIR, H. and ERYILMAZ, F. (2020), Türkiye'de İstihdam ve Reel Ücretler Arasındaki ilişki: Bir Zaman Serisi Analizi, Uluslararası Afro-Avrasya Araştırmaları Dergisi, 5 (10), 1-16.

BHATTACHARYA, M, NARAYAN, P., POPP, S. and RATH, B. N. (2009), The Productivity-Wage and ProductivityEmployment Nexus: A Panel Data Analysis of Indian Manufacturing, Empirical Economics, 40, 285-303.

BiLDIRICI, M. E. (2012), Türkiye'de İşsizlik Sorunsalı ve Gaziantep İçin Sonuçlar, Discussion Paper, No. 2012/85, Turkish Economic Association, Ankara. https://www.econstor.eu/bitstream/10419/81735/1/727025376.pdf, (Erişim Tarihi: 01.06.2019).

BRADLEY, M. E. (2007), Efficiency Wage and Classical Wage Theory, Journal of the History of Economic Thought, 26, 167-188.

BROWN, N. J. (1980), How Close to an Auction is the Labor Market?, Employee Risk a Version Income Uncertainty and Optimal Labor Contracts?, NBER Working Paper No:603, https://www.nber.org/system/files/working_ papers/w0603/w0603.pdf, (Erişim Tarihi: 10.11.2020).

BRUNHOFF, S. (1992), Devlet ve Sermaye, (Çev: K. Lordoğlu), Imge Kitabevi, 1. Baskı, Ankara.

ÇETIN, A. and BAKIRTAŞ, I. (2014), OECD Ülkelerinde Reel Ücretler ve Emek Verimliliği Arasındaki ilişki: Panel Veri Analizi, Dumlupınar Üniversitesi Sosyal Bilimler Dergisi, 39, 173-186.

DAS, P., BASU, R. and HALDER, A. (2017), Employment, Wage and Productivity: Analysis of Trend and Causality in Indian Manufacturing Industries, The Journal of Industrial Statistics, 6 (1), 41-56.

DICKEY, D. A and FULLER, W. A. (1981), Likelihood Ratio Statistics for Autoregressive Time Series with a Unit Root, Econometrica, 49 (4), 1057-1072.

DIMIAN, G. C., MARIN, E. and JABLONSKY, J. (2019), Investigating the Long and Short-Run Salary- Employment Relationship in Romania: A Sectorial Approach Using the ARDL Model, Economic Computation \& Economic Cybernetics Studies \& Research, 53 (1), 5-20.

DOBB, M. (2007), Kapitalizmin Gelişimi Üzerine İncelemeler: Geçiş Tartışmaları, İstanbul Belge Yayınevi.

DOĞRUYOL, A. and AYDINLAR, K. (2015), Emek Üretkenliği ve Ücret Teorisi, Çukurova Üniversitesi Sosyal Bilimler Enstitüsü Dergisi, 24 (2), 263-278.

DOSTIE, B. (2006), Wages, Productivity and Aging, Centre interuniversitaire sur le risque, les politiques économiques et l'emploi, Cahier de recherche/Working Paper 06-45, 1-30, https://depot.erudit.org/ bitstream/002023dd/1/CIRPEE06-45.pdf, (Erişim Tarihi: 30.01.2019).

ELGiN, C. ve KUZUBAŞ, C. T. (2012), Wage Productivity GAP in Turkish Manufacturing Sector, No 2012/03, Working Papers, Bogazici University, Department of Economics, 1-22, https://pdfs.semanticscholar. org/8ccc/294054232c67428629d7a516f7b0aab2e1dd.pdf, (Erişim Tarihi: 30.01.2019). 
EREN, E., BILDIRICI, M. E. and FIRAT, Ü. (2000), Türkiye'de 1998-1999 Krizinde Yönetici Davranışları, İstanbul Sanayi Odası, İstanbul.

FASHIN, S. and GAVOSTO, A. (2010), Trends of Labor Productivity in Italy: A Study with Panel Co-Integration Methods, International Journal of Manpower, 31 (7), 755-769.

FEDDERKE, J. W. and MARIOTTI, M. (2002), Changing Labor Market Conditions in South Africa: A Sectoral Analysis for the Period 1970-1997, South African Journal of Economics, 70 (5), 830-864.

FRIEDMAN, M. (1968), The Role of Monetary Policy, The American Economic Review, 58 (1), 1-17.

GOH, S. K. (2009), Is Productivity Linked to Wages? An Empirical Investigation in Turkey, Munich Personal RePEc (MPRA) Paper No:18095, pp.1-19. https://mpra.ub.uni-muenchen.de/18095/, (Erişim Tarihi: 01.06.2019).

GÜNEŞ, Ş. (2007), İmalat Sektöründe Verimlilik ve Reel Ücret İlişkisi: Bir Koentegrasyon Analizi, Yönetim ve Ekonomi, 14 (2), 275-287.

HARRISON, P. (2009), Median Wages and Productivity Growth in Canada and the United States, Center for the Study of Living Standards Research Note 2009-2, http://www.csls.ca/notes/note2009-2.pdf, (Erişim Tarihi: 06.06.2019).

HSIEH, C. T. and KLENOW, P. J. (2009), Misallocation and Manufacturing TFP in China and India, Quarterly Journal of Economics 124 (4), 1403-1448.

KATOWICH, E. S. and MAIA, A. C. (2018), The Relation Between Labor Productivity and wages in Brazil: A Sectoral Analysis, Nova Economica, 28 (1), 7-38.

KAYNAK, M. (2006), Türkiye’de Emek Kalitesi, TiSK Akademi, 1 (1), 67-86.

KAYTANCI, U. B. (2010), Etkin Ücret Teorisi ve Türkiye İmalat Sanayii Üzerine Uygulama, Ekonomik Yaklaşım Dergisi, 21 (76), 93-118.

KILIÇASLAN, Y. (2005), Industrial Structure and Labor Markets: A Study on Productivity Growth, Doctoral Dissertation, Middle East Techinical University, Ankara.

KLEIN, N. (2012), Real Wage, Labor Productivity and Employment Trends in South Africa: A Closer Look, Working Paper, International Monetary Fund, WP 12/92.

KORKMAZ, S. and YILGÖR, M. (2010), 2001 Krizinden Sonra Türkiye'de Büyüme ve İstihdam Arasındaki İlişki, Yönetim ve Ekonomi Araştırmaları Dergisi, 8 (14), 169-176.

KREGEL, J. A. (1983), Distribution, Effective Demand and International Economic Relations, Macmillian, London.

KRUEGER, B. and SUMMERS, L. (1988), Efficiency Wages and The Inter Industy Wage Structure, Econometrica, 56 (2), 259-263.

KWIATKOWSKI, D., PHILLIPS, P. C. B., SCHMIDT, P. ve SHIN, Y. (1992), Testing the Null Hypothesis of Stationarity Against the Alternative of a Unit Root, Journal of Econometrics, 54, 159-178.

LAZEAR, P. E. (1984), Incentives and Wage Rigidity, NBER Working Paper No: 1299.

LINDBECK, A. and SNOWER, D. J. (1985), Explanations of Unemployment, Oxford Review of Economic Policy, 1 (2), 34-59.

LINDBECK, A. and SNOWER, D. J. (1986), Wage Setting, Unemployment and Insider-Outsider Relations, The American Economic Review, 76 (2), Papers and Proceedings of the Ninety-Eighth Annual Meeting of the Amerian Economic Association, 235-239.

LOPEZ A. V. and SILVA, J. I. (2011), Employment Protection and the Non-Linear Relationship Between the WageProductivity GAP and Unemployment, Scottish Journal of Political Economy, 58 (2), 200-220.

LORDOĞLU, K., ÖZKAPLAN, N. and TÖRÜNER, M. (1999), Çalışma İktisadı (3. Baskı), Beta Yayıncılık, İstanbul.

MARELLI, E. and SIGNORELLI, M. (2010), Employment, Productivity and Models of Growth in the EU, Journal of Man Power, 31 (7), 732-754. 
MARQUETTI, A. (2004), Do Rising Real Wages Increase the Rate of Labor-Saving Technical Change? Some Econometric Evidence, Metroeconomica, 55 (4), 432-441.

MARX, K. (2000), Kapital, 1. Cilt, (Çeviren: Alaattin Bilgi), Sol Yayınları, 6. Baskı, Ankara.

MEGHAN, M. (2002), Disentangling the Wage-Productivity Relationship: Evidence from Select OECD Member Countries, International Advances in Economic Research, 8, 314-323.

MITCHELL, W. and MUYSKEN, J. (2008), Full Employment Abondoned: Shifting Sands and Policy Failures, http:// pombo.free.fr/mitchellmuysken.pdf, (Erişim Tarihi: 01.10.2020).

NARAYAN, P. K. and SMYTH, R. (2009), The Effect of Inflation and Real Wages on Productivity: New Evidence from a Panel of G7 Countries, Applied Economics, 41, 1285-1291.

OECD, (2017), Labor Force Statistics, https://data.oecd.org/emp/labor-force-participation-rate.htm\#indicatorchart, (Erişim Tarihi: 12.10.2019).

ÖZMuCuR, S. (2003), Wage and Productivity Differentials in Private and Public Manufacturing: The Case of Turkey, Industrial Organization 0303002, 1-17, University Library of Munich, Germany, http://citeseerx.ist.psu. edu/viewdoc/download?doi=10.1.1.533.2359\&rep=rep1\&type=pdf, (Erişim Tarihi: 12.10.2019).

ÖZTÜRK, N. (2005), Ücret Kuramında Yeni Yaklaşımlar, Gazi Üniversitesi İktisadi ve İdari Bilimler Fakültesi Dergisi, 7 (1), 29-49.

PARASIZ, İ. (1994), Ücret Teorisi: Modern Yaklaşım, Ezgi Kitabevi, Bursa.

PARASIZ, İ. and BILdiRici, M. E. (2002), Modern Emek Ekonomisi, Ezgi Kitabevi, Bursa.

PERRON, P. (1997), Further Evidence on Breaking Trend Functions in Macroeconomic Variables, Journal of Econometrics, 80 (2), 355-385.

PESARAN, M. H. and PESARAN, B. (1999), An Autoregressive Distributed Lag Modelling Approach to Cointegration Analysis, in (ed) S. Storm, Econometrics and Economic Theory in the 20th Century, The Ragnar Frisch Centennial Symposium, Chapter 11, Cambridge Univ. Press, Cambridge.

PESARAN, M. H., SHIN, Y. and SMITH, R. J. (2001), Bounds Testing Approaches to the Analysis of Level Relationships, Journal of Applied Econometrics, 16, 289-326.

PETRIN, A. and SIVADASAN, J. (2006), Job Security Does Affect Economic Efficiency: Theort, a New Statistic and Evidence from Chile, NBER Working Paper No 12757, 1-55.

PHELPS, E. S. (1967), Philips Curves, Expectations of Inflation and Optimal Unemployment Over Time, Economica, 43, 254-281.

PHILIPS, A. (1958), The Relationship Between Unemployment and the Rate of Change of Money Wages in UK, 1861-1957, Economica, 25 (200), 283-299.

PHILLIPS, P. C. B. and PERRON, P. (1988), Testing for a Unit Root in Time Series Regression, Biometrika, 75 (2), 335-346.

SAPANCALI, F. (2008), Türkiye'de İş Gücü Piyasası, Sorunlar ve Politikalar, TUHíS İş Hukuku ve İktisat Dergisi, $21(2-3), 8-30$.

SARAÇOĞLU, B. and SUIÇMEZ, H. (2008), Türkiye İmalat Sanayinde Büyüme, İstihdam ve Verimlilik Sorunları, TiSK Akademi, 3 (6), 88-126.

SHARPE, A., ARSENAULT, J. F. and HARRISON, P. (2008), The Relationship Between Productivity and Real Wage Growth in Canada and OECD Countries, 1961-2006, CSLS Research Reports 2008-08, Centre for the Study of Living Standards, 1-83, http://www.csls.ca/reports/csls2008-8.pdf, (Erişim Tarihi: 10.07.2019).

SMITH, A. (1997), Ulusların Zenginliği, (Çeviren: A. Yunus, M. Bakırcı), Alan yayıncılık, 2. Baskı, İstanbul.

STRAUSS, J. and WOHAR, M. E. (2004), The Linkage Between Prices, Wages and Labor Productivity: A Panel Study of Manufacturing Industries, Southern Economic Journal, 70 (4), 920-941. 
SYMEONIDIS, G. (2008), The Effect of Competition on Wages and Productivity: Evidence from the UK, The Review of Economics and Statistics, 90 (1), 134-146.

TADJOEDDIN, M. Z. (2016), Earnings, Productivity and Inequality in Indonesia, The Economic and Labor Relations Review, 27 (2), 248-271.

TADJOEDDIN, M. Z. and CHOWDHURY, A. (2019), Employment and Re-Industrialisation in Post Soeharto Indonesia, Critical Studies of The Asia-Pacific, Palgrave MacMillan.

TAŞTAN, H. and AKAR, M. (2013), Türkiye İmalat Sanayiinde Bölgesel ve Sektörel Ücret Eşitsizliği, İktisat Fakültesi Mecmuası, 63 (1), 17-49.

TAYMAZ, E., VOYVODA, E. and YILMAZ, K. (2014), Demokrasiye Geçiş, Reel Ücretler ve Verimlilik: Türk İmalat Sanayiinden Bulgular, Koç University TUSIAD Economic Research Forum Working Paper Series, 1408, 1-18.

TODA, H. Y. and YAMAMOTO, T. (1995), Statistical Inference in Vector Autoregressions with Possibly Integrated Processes, Journal of Econometrics, 66 (1-2), 225-250.

WAKEFORD, J. (2004), The Productivity-Wage Relationship in South Africa: An Empirical Investigation, Development Southern Africa, 21 (1), 109-132.

YALÇıNTAŞ, N. (1969), Ücretler ve Emek Arzı, İstanbul Üniversitesi İktisat Fakültesi Yayın No: 252, Fakülteler Matbaası, İstanbul.

YILDIRIM, Z. (2015), Relationships Among Labor Productivity, Real Wages and Inflation in Turkey, Journal Economic Research-Ekonomska Istraživanja, 28 (1), 85-103.

\section{APPENDICES}

Appendix 1.Determining the Optimal Lag Length of the VAR System

\begin{tabular}{|c|c|c|c|c|c|c|}
\hline Lag & LogL & LR & FPE & AIC & SC & HQ \\
\hline 0 & 94,36580 & NA & $1,75 e-06$ & $-4,742544$ & $-4,346665$ & $-4,604372$ \\
\hline $\mathbf{1}$ & $\mathbf{1 7 6 , 4 1 8 0}$ & $\mathbf{1 3 6 , 7 5 3 6 *}$ & $\mathbf{3 , 0 5 e - 0 8 *}$ & $\mathbf{- 8 , 8 0 0 9 9 8}$ & $\mathbf{- 8 , 0 0 9 2 3 8 *}$ & $\mathbf{- 8 , 5 2 4 6 5 2}$ \\
\hline 2 & 181,5108 & 7,639306 & $3,88 \mathrm{e}-08$ & $-8,583935$ & $-7,396296$ & $-8,169417$ \\
\hline 3 & 187,9221 & 8,548418 & $4,69 e-08$ & $-8,440119$ & $-6,856600$ & $-7,887428$ \\
\hline 4 & 200,3139 & 14,45709 & $4,22 \mathrm{e}-08$ & $-8,628552$ & $-6,649153$ & $-7,937689$ \\
\hline 5 & 216,9405 & 16,62659 & $3,16 e-08$ & $-9,052251$ & $-6,676973$ & $-8,223215$ \\
\hline 6 & 226,0982 & 7,631368 & $3,86 e-08$ & $-9,061009$ & $-6,289851$ & $-8,093801$ \\
\hline 7 & 233,3358 & 4,825085 & $5,88 e-08$ & $-8,963099$ & $-5,796061$ & $-7,857718$ \\
\hline 8 & 257,0527 & 11,85847 & $4,32 e-08$ & $-9,780707^{*}$ & $-6,217789$ & $-8,537153^{*}$ \\
\hline
\end{tabular}

Note: *Indicates the optimal lag length. According to diagnostic tests and the AR graph, the optimal lag was determined to be 1. 


\section{Appendix 2. Inverse Roots of the AR Characteristic Polynomial}

Inverse Roots of AR Characteristic Polynomial

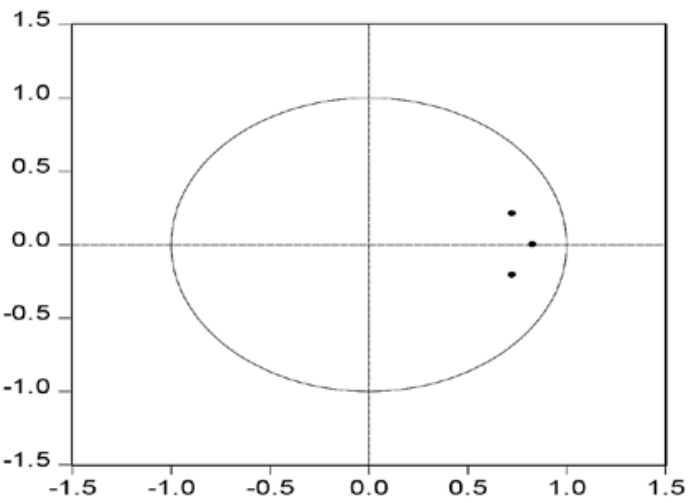

Appendix 3. Results of the Toda-Yamamoto Causality Test

\begin{tabular}{|c|c|c|c|c|}
\hline Null Hypothesis & & MWald Statistics & p-Value & Decision \\
\hline \multirow{3}{*}{$\begin{array}{l}\text { Labor productivity and unemployment } \\
\text { do not causally affect real wages. }\end{array}$} & $\mathrm{H}_{0}: \beta_{1 i}=\beta_{2 i}=\beta_{3 i}=\beta_{4 i}=0$ & 1,3241 & 0,5158 & Accept \\
\hline & $\mathrm{H}_{0}: \beta_{1 i}=\beta_{2 i}=0$ & 0,6049 & 0,4367 & Accept \\
\hline & $\mathrm{H}_{0}: \beta_{3 i}=\beta_{4 i}=0$ & 0,0005 & 0,9815 & Accept \\
\hline \multirow{3}{*}{$\begin{array}{l}\text { Wages and unemployment do not } \\
\text { causally affect labor productivity. }\end{array}$} & $\mathrm{H}_{0}: \mathrm{a}_{1 i}=\mathrm{a}_{2 i}=\mathrm{a}_{3 i}=\mathrm{a}_{4 i}=0$ & 6,8321 & $0,0328^{b}$ & Reject \\
\hline & $\mathrm{H}_{0}: \mathrm{a}_{1 i}=\mathrm{a}_{2 i}=0$ & 0,0984 & 0,7537 & Accept \\
\hline & $\mathrm{H}_{0}: \mathrm{a}_{3 i}=\mathrm{a}_{4 i}=0$ & 6,7079 & $0,0096^{c}$ & Reject \\
\hline \multirow{3}{*}{$\begin{array}{l}\text { Wages and labor productivity do not } \\
\text { causally affect unemployment. }\end{array}$} & $\mathrm{H}_{0}: \gamma_{1 i}=\gamma_{2 i}=\gamma_{3 i}=\gamma_{4 i}=0$ & 6,9365 & $0,0312^{\mathrm{b}}$ & Reject \\
\hline & $\mathrm{H}_{0}: \gamma_{1 i}=\gamma_{2 i}=0$ & 1,8338 & 0,1757 & Accept \\
\hline & $\mathrm{H}_{0}: \gamma_{3 i}=\gamma_{4 i}=0$ & 4,8123 & $0,0283^{b}$ & Reject \\
\hline \multicolumn{5}{|l|}{ Assumptions for VAR Model } \\
\hline Test & \multicolumn{2}{|c|}{ Test Statistics } & \multicolumn{2}{|c|}{ p-Value } \\
\hline Breusch-Godfrey LM & \multicolumn{2}{|c|}{8,1867} & \multicolumn{2}{|c|}{0,5179} \\
\hline Breusch-Pagan Godfrey & \multicolumn{2}{|c|}{198,0412} & \multicolumn{2}{|c|}{0,4858} \\
\hline
\end{tabular}

Note: The optimal lag length ( $k$ ) of the VAR model was determined to be 1 and $d_{\text {max }}$ was taken as 1 . In addition, a, $b$ and $c$ are statistically significant at $10 \%, 5 \%$ and $1 \%$ respectively. The assumptions of homoscedasticity and no autocorrelation are valid for $1 \%$ significance in the VAR model. $p$-values are given in parentheses. 